
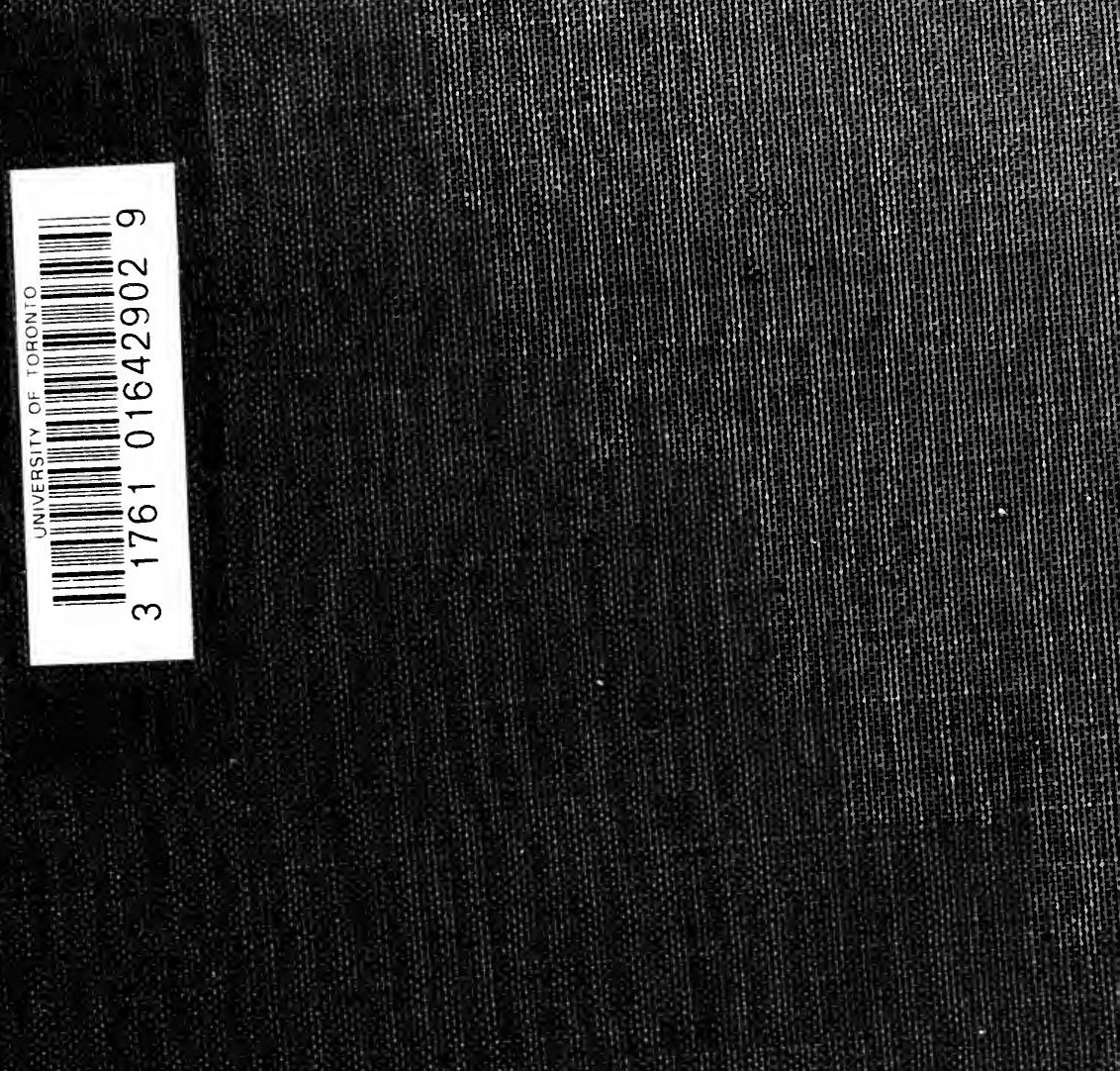

Digitized by the Internet Archive in 2007 with funding from Microsoft Corporation 



\title{
THE LEAGUE OF NATIONS
}

AND THE

\section{NEW INTERNATIONAL LAW}

BY

JOHN EUGENE HARLEY, A.M.

FORMERLY CARNEGIE FELLOW IN INTERNATIONAL LAW HARVARD UNIVERSITY

ASSISTANT PROFESSOR OF POLITICAL SCIENCE, UNIVERSITY OF SOUTHERN CALIFORNIA

\author{
NEW YORK \\ OXFORD UNIVERSITY PRESS \\ AMERICAN BRANCH: 35 WEsT 32ND STREET \\ LONDON, TORONTO, MELBOURNE AND BOMBAY
}


Copyright, I921

by OXford University Press

AMERICAN BRANCH

Printed in U. S. A. 
To

MY MOTHER

AND

\section{THE AMERICAN BOYS WHO}

DIED IN FRANCE

"It is wicked not to try to live up to high ideals and to better the condition of the world." - Theodore Roosevelt

December 11, 1918 



\section{INTRODUCTION}

That for which Hugo Grotius plead is coming to pass: war is to be outlawed. Certain kinds of war are to be regarded, for the first time in history, as illegal; and, that which is of equal importance, the nebulous thing known as international law is, likewise, for the first time in history, to have a sanction so that the word "illegal" as applied to the action of States will have real significance.

This is the subject of Mr. Harley's treatise. Few things could be more timely and few statements could be more basic, more refreshingly new nor more happily made. Take this bit, summarizing the kinds of war which are now become illegal for the signatories to the Paris Covenant:

"1. A war of conquest or external aggression is illegal;

"2. A war resorted to by one member after the matter in dispute has been the subject of an arbitral award which is complied with by the other disputant is an illegal war;

"3. A war is illegal if resorted to by a member in disregard of a unanimous recommendation by the Council (excluding disputants) which is complied with by the other disputing member;

"4. All wars between members of the League are illegal if begun before a delay period of from three to nine months has elapsed."

Under the Paris Covenant a signatory beginning war illegally is deemed, ipso facto, to "have committed an act of war against all other members of the League," who must thereupon discontinue intercourse of every kind with the offender and may be called upon to make war upon it. 
Isn't this worth while, even if the Covenant had done nothing more? But the Covenant does much more. Besides planning new instruments for settling disputes peacefully, such as the court of law, the Council and the Assembly; for controlling the armament madness - the sense of security which will follow the punishment of the wanton aggressor will make this possible - for united action to better the conditions of labor, the Covenant plans that great step toward more enduring peace, namely, the definition of that law under the reign of which the nations may live together and compose their interests just as the individual has long done under municipal law. Mr. Harley points out that these ends are to be achieved by a "new international person" to which the nations surrendered only those attributes of sovereignty needed to effect the purpose in view. In so doing they feel that they are making the residue and more vital part of their sovereignty - that which was retained by them - more secure from outside interference and attack. This is nothing other than the principle, long ago recognized, that true liberty is attainable only through a surrender of license - in this case the license to indulge in the pastime of war whenever it suited a people or their rulers to do so. Under the League, something of that license still persists, but much of it, as we have seen, is gone. Another sovereign right hitherto highly prized, the right to remain neutral, was likewise surrendered in the common interest. The aim of the surrender, as Mr. Harley sees it, is to clothe a " continuous international agency" with just so much power as will make reasonable of expectation " the maintenance of international peace and security, and the promotion of international coöperation, through the development of international law." This agency is not a State, for the territories of the nations 
which have set it up are not its territories and their peoples are not its nationals. According to Mr. Harley's view, it does not exercise the powers which Confederations have usually exercised, and, at the same time, is more than an Alliance the action of which is not continuous but which, as a rule, comes into play only under specified conditions. At the same time, this "new international person," the League of Nations, is a subject of international law, its officials and representatives enjoy diplomatic privileges and immunities when engaged on the League's business, and in connection with its trusteeship of the Saar Basin it is vested with legal title to, and authority over, the actual territory administered.

It will be seen, from this brief introduction, what new problems Mr. Harley is here dealing with and what interest and importance attaches to them.

Theodore Marburg 



\section{CONTENTS}

Introduction. By Theodore Marburg, former United States Minister to

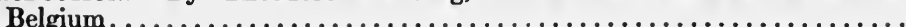

\section{CHAPTER I}

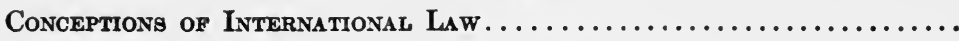

CHAPTER II

Methods by which International Law is Developed..............

CHAPTER III

Codification of International Law

CHAPTER IV

The International Labor Organization

CHAPTER V

INTERNATIONAL LAW DURING THE WAR.

CHAPTER VI

In Certain Caseg War made an Iluegal Process by the Covenant...

CHAPTER VII

Settlement of Disputes. . . . . . . . . . . . . . . . . . . . . . . . .

\section{CHAPTER VIII}

Some Modifications in the Theory of International Law.

\section{CHAPTER IX}

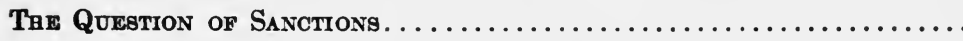

\section{CHAPTER $\mathrm{X}$}

The Junidical Status of the League of Nations.................

\section{CHAPTER XI}

Conclusions.

58-59

\section{APPENDICES}

I. The Smuts Proposals for a League of Nations...............

II. A Draft of the Composite Covenant made by the Legal Advisers of the Commission on the League of Nations.............

III. The Original and Revised Drafts of the Covenant arranged in

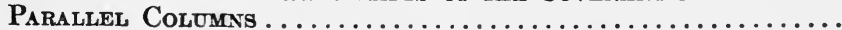

IV. Table showing International Administrative Organizations.....

V. Table of the Cases decided by the Permanent Court of Arbitra-

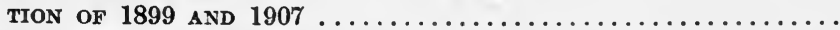

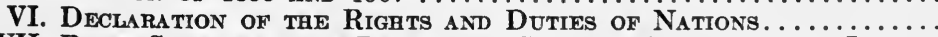

VII. Draft Scheme for the Permanent Court of International JUstice VIII. Council's Letter submitting Court Scheme to the Governments

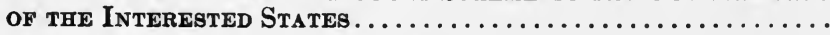





\section{THE LEAGUE OF NATIONS \\ AND THE \\ NEW INTERNATIONAL LAW}

\section{CHAPTER I}

CONCEPTIONS OF INTERNATIONAL LAW

“By painful stage after stage," said President Wilson, "has that law [international law] been built up with meager enough results indeed after all was accomplished that could be accomplished, but always with a clear view at least of what the heart and conscience of mankind demanded." 1 Some of those stages, which are referred to by the President, include the academic struggle which has been more or less in evidence since the time of Grotius, as to what conception of international law was correct, if, indeed, there was any law at all, which has by some writers been seriously questioned. The conceptions which have received any considerable following will be considered briefly.

The Grotian School. - Properly enough the conception of international law held by Grotius has been made the basis for the discussions of later writers and statesmen. This great Dutch jurist, who is well called the father of international law, set forth his views in 1625 in a work that has become a classic. "Natural law," he believed, "is the dictate of right reason, pronouncing that there is in some actions a moral obligation, and in other actions 
a moral deformity, arising from their respective suitableness or repugnance to the rational and social nature, and that consequently such actions are either forbidden or enjoined by God the author of nature. Actions which are the subject of this exertion of reason are in themselves lawful or unlawful, and are, therefore, as such necessarily commanded or prohibited by God. . . :" 1

"In the subject now in question [that is, natural and international law] this cause [of concurring sentiment of writers, historians and philosophers] must be either a just deduction from the principle of natural justice, or universal consent. The first discovers to us the natural law, the second the law of nations. . . . If a certain maxim, which cannot be fairly inferred from admitted principles, is, nevertheless, found to be everywhere observed, there is reason to conclude that it derives its origin from positive institution." 2

Grotius saw clearly enough that the law of nature was of itself insufficient for governing the intercourse between nations, and he recognized that principles of international law arose by agreement of minds and by common consent found in custom and tacit compact (moribus et pacto tacito introductum). ${ }^{3}$ This class of law he called jus gentium voluntarium or jus constitutum. Here is seen a distinction between natural law and the law of nations which is created by positive institution: a distinction which gave rise to the two schools of international law called the naturalists and the positivists. The difference between natural law and international law, as conceived by Grotius, was that the former is a body of necessarily existing, fundamental principles determined by God, the author of nature, without

1 De Jure Belli ac Pacis, lib. I, cap. I, sect. X, 1, \&.

2 Ibid., Prolog. sect. XLI. ' Ibid., sect. XVII. 
which nations as such cannot exist. The latter is a body of laws created by universal consent, positive institution, and agreement of the collective opinion of mankind.

The Hobbes' Conception. - The philosopher Hobbes identified natural law and international law. Writing in 1647 , about two decades after Grotius' great work appeared, he stated that "natural law may be divided into the natural law of men and the natural law of States, commonly called the law of nations. The precepts of both are the same; but since States, when they are once instituted, assume the personal qualities of individual men, that law, which when speaking of individual men, we call the law of nature, is called the law of nations when applied to whole States, nations, or peoples." 1 While Hobbes here identifies natural and international law, he does differentiate the subjects to which each applies. In his conception there is no place for positive or instituted law which was conceived by his predecessor, Grotius.

Pufendorf's Conception. - The German writer, Pufendorf, who while ambassador to Switzerland, was imprisoned in violation of international law, wrote a volume on international law while he was in prison. Doubtless he was inspired to his task by the breach of the age-long principle of inviolability of an ambassador's person and premises and by the further fact that he had ample time, while in his lonely prison cell, to set down his thoughts. "Natural law," he wrote, "is that which is so exactly fitted to suit with the rational and social nature of man that he cannot maintain peaceful fellowship without it. Positive law, on the other hand, is sometimes called voluntary, because no positive law has such an agreeableness with human nature as to be necessary in general for the preservation of man-

${ }^{1}$ De Cive, cap. XIV, sect. 4 (1647). 
kind, or as to be known or discovered without the help of express and peculiar promulgation." 1

Elsewhere, he held that positive international law actually flows from natural law, besides which there is " no other sort of law of nations, voluntary or positive, at least which has the force of law properly so called, binding upon nations as emanating from a superior." 2 It is here seen that Pufendorf practically identifies natural law, and international law, which he believed had no force unless it were founded on natural law itself.

Phillimore's Conception. - The eminent English authority, Sir Robert Phillimore, has expressed in very clear terms the relation between natural and positive law:

"The necessity of mutual intercourse is laid down in the nature of States, as it is of individuals, by God, who willed the State and created the individual. The intercourse of nations, therefore, gives rise to international rights and duties, and these require an international law for their regulation and enforcement. That law is not enacted by the will of any common superior upon earth, but it is enacted by the will of God; and it is expressed in the consent, tacit or declared, of independent nations. The law which governs the external affairs, equally with that which governs the internal affairs, of States receives accessions from custom and usage, binding the subjects of them as to things which, previous to the introduction of such custom and usage, might have been in their nature indifferent. Custom and usage, moreover, outwardly express the consent of nations to things which are naturally, that is, by the law of God, binding upon them. But it is to be remembered that, in this

1 Law of Nature and of Nations, Book I, ch. IV, sect. 18.

2 Ibid., Book II, ch. III, sect. 23. 


\section{THE NEW INTERNATIONAL LAW}

latter case, usage is the effect and not the cause of the law." 1

The Austinian School. - The English jurist, Austin, and others who have looked to him as the expounder of their views, denied that international law was law at all, in the true sense. He thought that there was no international law in the same sense that there is a municipal law, because there was no common political superior to enforce the former. His view is the more interesting when the sanctions established by the Covenant are kept in mind. He wrote thus in 1832:

"Laws are commands proceeding from a determinate rational being, or a determinate body of rational beings to which is annexed an eventual evil as the sanction. Such is the law of nature, more properly called the law of God, or the divine law; and such are political human laws prescribed by political superiors to persons in a state of subjection to their authority. But laws imposed by general opinion are styled laws by an analogical extension of the term. Such are the laws which regulate the conduct of independent political societies in their mutual relations, and which are called the law of nations or international law. The law obtaining between nations is not positive law; for every positive law is prescribed by a given superior or sovereign to a person or persons in a state of subjection to its author. The rule regarding the conduct of sovereign States, considered as related to each other, is termed law by its analogy to positive law, being imposed upon nations and sovereigns, not by the positive command of a superior authority, but by opinions generally current among nations. The duties which it imposes are enforced by moral sanctions: by fear on the part of nations, or by fear on the part of

1 International Law, I, Preface (1832); italics mine. 
sovereigns, of provoking general hostility, and incurring its probable evils, in case they should violate maxims generally received and respected." 1

The Conception of International Law under the League of Nations. - From these conceptions of international law held from the time of Grotius down to the present time, what satisfying conclusions can be drawn? Can these older views be restated or harmonized in such a way that a student of international law may not be confused by a variety of conceptions of his science? And, finally, what conception best harmonizes with the underlying principles of the League?

It is evident at the outset that the view of Austin and those who hold that international law is not positive law must be discarded. One has only to cite that section of the Versailles Treaty which provides for the trial of certain Germans for the violation of the laws and customs of war to convince those who are inclined to doubt the existence of positive law for the nations. ${ }^{2}$ Additional evidence is furnished by the sanction article of the Covenant which provides punishment for those members who disregard the principles agreed to in the document (Article XVI). The inadequacy of the Austin view is well pointed out by the English writer, T. J. Lawrence. He shows that Austin's conception of law utilizes " one element only [that is, force] in the ordinary conception of law, elaborating it to the exclusion of the rest." 3 Instead of making the definition of international law turn on force, Mr. Lawrence suggests that the universal desire for order should be the essential

${ }^{1}$ Province of Jurisprudence, pp. 147-148. (London, 1832.)

${ }^{2}$ See Article 4 of the new German constitution, footnote to Appendix VI. This article declares that the principles of international law are recognized as an integral part of the law of the German Commonwealth.

3 International Law, p. 12 (Boston, 1900). 
element in the definition. The underlying philosophy of the League of Nations is just that. The purpose of the League is to make international law the actual rule of conduct to the end that international order may be maintained. To accomplish this purpose it adopts certain sanctions which will be used as a last resort, but the desire for order as expressed by the public opinion of the world is the true and ultimate force which will sustain the League in its effort to maintain order through international law.

Public opinion is based on natural law which is that body of rules of justice and right which God the author of these rules unfolds to nations in their intercourse with one another. But these rules must be expressed. They cannot all be expressed at once; as nations progress, however, more and more of the natural laws are adapted as positive international laws. They are made known to all nations through the five methods of development of international law outlined elsewhere in this study. ${ }^{1}$ Until so expressed and made known, they are only potential. They are, to adapt the phrase of Phillimore, binding upon States in matters which, "previous to the introduction of custom and usage, might have been in their nature indifferent. . . . Usage [and this last statement applies to the other methods of developing the law] is the effect and not the cause of the law." 2

1 Pp. 8-13.

2 International Law, I, Preface (1832); italics mine. 


\section{CHAPTER II}

\section{METHODS BY WHICH INTERNATIONAL LAW IS DEVELOPED}

There are five methods by which international law comes into being: first, by agreement of eminent authorities upon a principle; second, by custom; third, by treaties; fourth, by judicial decisions; and fifth, by international congresses.

Writers. - Concerning this method of developing the law, the observation of Triepel respecting the right of enemy merchantmen to oppose capture, is to the point: "Es ist hier wie so oft in unserer Diziplin gegangen: der Spätere schrieb von den Früheren ab, ohne sich viel Gedanken zu machen." 1

While the influence of learned writers upon the development of international law has been considerable, ${ }^{2}$ in the very nature of things their opinions can only aid in the slow process of developing the law. Particularly is this true regarding questions which are of a broad and complex nature or which involve national interest. In no better way can this point be illustrated than by a consideration of the opinions of authorities concerning the great law of angary which was applied by the Allied and Associated Powers, particularly the United States and Great Britain, when they took over $1,000,000$ tons of Dutch shipping in

1 H. Triepel, "Widerstand feindlicher Handelsschiffe gegen die ¿Aufbringung," Zeitschrift für Völkerrecht, VIII, p. 392.

2 Upon receiving some copies of Vattel's work on international law, Benjamin Franklin wrote in $\mathbf{1 7 7 5}$ that it had come to him "in good season, when the circumstances of a rising State made it necessary frequently to consult the law of nations," and that the work "has been continually in hands of the members of our Congress now sitting." Wharton's Diplomatic Correspondence of the American Revolution, II, p. 64. 
1918 during the World War. The range of opinions regarding this law extended from those denying entirely the right to apply the law, to those which held it might be applied even in case of a customary military necessity. Among sixty-eight authorities treating the subject, fifty were of the opinion that the law was applicable, while eighteen believed that it was not. ${ }^{1}$ Other examples of questions as to which wide difference of opinion exists among authorities is the obligation to ratify treaties, and the immunity of private property from capture at sea.

Custom. - A rule of customary law may be described as a rule which is legally necessary and permissible and which develops from oft-repeated practices and procedure among the nations. The body of rules respecting ambassadors and ministers have largely developed by this method. The diplomatic privileges and immunities which these representatives enjoy are for the most part the outcome of a long historical and cumulative growth.

The international commission and administrative agencies develop customary international law. Speaking of the international commissions which served in connection with the making of the Versailles Treaty of 1919, Professor Charles H. Haskins of Harvard who served on the Saar Basin Commission said: " Considered at first as gatherers and sifters of evidence these commissions tended to acquire more responsibility and to make their reports in the form of draft articles for the treaty. ... The historian of the future will be able to compare the printed minutes and reports, and see how far they were followed." 2

While the temporary commissions thus actually wrote

1 J. E. Harley, “The Law of Angary,” Am. Jour. Int. Law, April, 1919, p. 275.

2 From a lecture delivered in Boston under the auspices of the Lowell Institute, Jan. 6, 1920. Boston Evening Transcript, Jan. 7, 1920. 
into the treaty principles, some of which will become international law by virtue of being agreed to by many nations, the more permanent commissions should, in the nature of the case, be more fruitful in developing principles of the law. After the Lower Danube Commission had been in operation for some time, the European Powers which took part in that commission declared that the arrangement relating to the administration of the river "henceforth forms a part of the public law of Europe and is placed under their guarantee." ${ }^{1}$ It is from the numerous commissions set up by the League Covenant and the Versailles Treaty that international law will derive many of its principles.

Treaties. - The so-called conventional international law is developed by treaties. When treaties between a considerable number of nations, particularly the great Powers, substantially agree as regards a given subject, the principles so agreed on are soon regarded as international law. As in case of customary law, however, this method of developing the law is slow. Changing conditions develop needs which should be met before waiting for conventional law to be brought into being. Moreover, the conventional method is an inadequate way of attaining universal recognition of a rule. Carried to the extreme case, each Power would by this method have to make a treaty with every other Power, and if 48 Powers are considered, a total of 1128 treaties would have to be made. ${ }^{2}$

The network of conciliation treaties concluded by Mr. Bryan in 1913 and 1914 while he was Secretary of State went far on the road toward universality, but only

1 Edward Krehbiel, "The European Commission of the Danube," Polit. Sci. Quart. March, 1918, p. 38.

2 If $n$ is the number of Powers, the number of possible treaties is expressed by the formula $\frac{n(n-1)}{2}$. 
thirty such treaties were concluded between the United States and other Powers. How much more satisfactory is it to sign a common document like The Hague Conventions or the Versailles Covenant!

Judicial Decisions. - The principles laid down by the judicial decisions of national courts often receive acceptance as principles of international law, particularly prize decisions. $^{1}$ The judge who sits on a prize case is expected to apply international law to that case. Some judges, notably Lord Stowell of Great Britain, have been so far able to disregard national prejudice that they have rendered decisions of remarkable fairness, and have actually applied international law as it relates to prizes.

The Constitution of the United States is not now what it was in 1789. During the course of the one hundred and thirty years of its life, it has been given a wealth of new meaning in accordance with the changing conditions of the country. Learned judges have read into its four corners meanings of which its framers never dreamed, but those interpretations have been admirably consistent with the spirit of the great document. A great body of law which today governs the United States is found in the reports of the decisions of the Supreme Court.

In the field of international law fifteen cases have been decided by the court established by the conventions of 1899 and 1907, signed at The Hague. Undoubtedly these decisions will form precedents. Speaking of the 1907 project for a Judicial Arbitration Court, Dr. James Brown Scott said: "It was felt that there would be continuity in their (the judges') decisions, with the result that international

1 The Carnegie Endowment is publishing American Prize Decisions, embracing 179 cases heard by the Supreme Court of the United States between 1789 and 1918 . See note Am. Hist. Rev. Jan. 1920, p. 355. 
law would be developed by its judgments, just as national law is developed by the decisions of national courts." 1 The proposed Permanent Court of International Justice should give continuity to international law.

International Congresses. - Finally, the most prolific and the most satisfactory method of developing international law is by means of the international congress. From such congresses, remarks Professor Krehbiel, " codified law springs into being full-fledged." ${ }_{2}$ Various congresses formulated principles which up to the time of the first Hague Conference had been accepted as international law. Among the most important of these might be mentioned the Congress of Paris, 1856, and the Geneva Congress of 1864. Many of the principles agreed on at the latter congress were incorporated into the Hague Conventions, particularly Conventions IV and X of 1907. They form the most authoritative existing statement of international law applicable to the matters with which they treat. The second Hague Conference made the accomplishment of the first its point of departure, improving upon certain parts of the work of the first conference and adding new principles to meet new conditions. So universally were the Hague regulations recognized as the latest and most authoritative statement of international law regarding the subject-matter treated that all recent texts base their discussions upon these provisions, in many cases quoting widely therefrom.

Even before the formulation of the League Covenant, leading students of international affairs expressed cogently their belief that further advancement should be made upon the foundations laid at The Hague. "The Conventions

1 Judicial Settlement of International Disputes, Feb. 1914, p. 9.

2 "The European Commission of the Danube," Pol. Sci. Quart., March 1918, p. 49. 
adopted at the Hague Conferences," said Professor Fenwick, "are undoubtedly a step forward in the task of codifying international law, for with all their limitations they represent an attempt on the part of the nations to define the common practice of the past with the addition of many new rules of a progressive character." 1 "In my opinion," said the eminent English authority, Oppenheim, "a League of Nations should start from where the two Hague Conferences have left the work." 2 Likewise President Butler of Columbia believed that "if the votes of the two Hague Conferences of 1899 and 1907 be taken as a starting point it should not be difficult to put into the draft plan a succinct statement of the principles of international law upon which the whole civilized world will agree." ${ }^{3}$ In his letter of March 29, 1919 to Mr. Hays, Mr. Root stated that "the two great international conferences at The Hague in 1899 and $1907 \ldots$ made great progress in agreeing upon and codifying the rules of international law which this court [the permanent court of arbitration] was to administer."

From these considerations the conclusions may be drawn that leading students are agreed, first, that international congresses are the best channel by which international law can be developed; and second, that the work of the congresses at The Hague should be made the basis of future endeavor.

1 Fenwick, C. G., "Codification of Int. Law," Am. Pol. Sci. Rev., May, 1918, p. 301.

2 World Court, Feb., 1918, p. 74.

s "The Period of Aloofness is Past," World Court, March, 1919, p. 208. 


\section{CHA P T E R III \\ CODIFICATION OF INTERNATIONAL LAW}

Realizing the unsatisfactory condition of international law, many authorities and societies have suggested that in so far as the development in certain branches have made it practicable, international law should be definitely formulated and codified. It is certain that there is a need for improvement in the condition in which international law now stands.

Two notable attempts to draw up draft codes have been made by individuals, both in the year 1872. In the preface to his Draft Outlines of an International Code, David Dudley Field, the American jurist, explains how he came to undertake such a task. It was the original plan as proposed by Mr. Field before the British Association for the Promotion of Social Science, to have jurists of several nations assigned a special field upon which to formulate the laws; they were to exchange their views and finally agree upon a completed draft. As might be expected from the difficulties of such a gigantic task, the original plan was not carried through, although the jurists were actually appointed. With a resolution which must have been remarkable, Mr. Field essayed the task of drawing up the bare outlines of a complete code of international law. It was a noble attempt but such a task can not be undertaken by any one individual, however learned.

In the same year the German publicist, Bluntschli, published a volume in which he attempted to set forth the 
principles of international law in draft form. ${ }^{1}$ He was influenced by letters received from Francis Lieber who had drawn up a code for the guidance of the American armies in the field. " $\mathrm{Thr}$ glücklicher Gedanke, der amerikanischen Armee ein kurz gefasstes Kriegsrecht als Instruction ins Feld mitzugeben, und mit Mahnungen des Rechts die wilden Leidenschaften des Kriegs möglichst zu zähmen, hat mich zuerst $\mathrm{zu}$ dem Vorsatze angeregt, die Grundzüge des modernen Völkerrechts in Form eines Rechtsbuchs darzustellen, und Thre Briefe haben mich ermuthigt, dieses Wagniss durchzuführen. Ihre Kriegsartikel haben durch die Autorität des Präsidenten Lincoln eine amtliche Verstärkung erhalten, welche mein Rechtsbuch völlig entbehren muss." 2

Like Field's code the work of Bluntschli failed to receive acceptance as a universal code, although it had considerable influence in fixing many principles. The work of Lieber formed the basis of the laws and customs of war on land which were formulated at the Brussels Conference in 1874 and revised by the Hague Conference of 1899 . It also suggested the possibility of drawing up rules for maritime warfare, and in 1899 the Powers signatory to the third Hague Convention, "adapted to maritime warfare the principles of the Geneva Convention of 22d August, 1864." 3

Is the Assembly of the League to be a body which will agree upon principles of international law applicable to all members of the League? In the composite plan submitted by Léon Bourgeois to President Wilson and the Premiers of France, Italy, and Great Britain, the fourth

1 Das moderne Völkerrecht der civilisierten Staaten als Rechtsbuch dargestellt (1872).

2 Quoted by Dr. Bluntschli in the preface to his Draft Code.

- Preamble to Convention III of 1899. 
point provided that the members of the League should " establish an international representative council which will provide for the development of international law." 1

In answer to President Wilson's request that neutrals send in proposed amendments to the original draft of the Covenant, the International Conference ${ }^{2}$ of the League of Nations Societies which met at Berne from March 6-13, 1919, suggested that " an international Parliament elected by the people should replace the assembly of delegates proposed in the Paris text. This Parliament should have full prerogatives and legislative powers, each country electing one member for each 1,000,000 inhabitants." The Commission on the League of Nations properly decided that the world is not yet ready for such a Parliament. Periodic congresses are at present the most feasible and satisfactory method of developing the law.

The fourth point of the program of the League to Enforce Peace, adopted November 23, 1918, provides for a "representative Congress to formulate and codify rules of international law." The third point of the program of the World Court League likewise provides for " periodic international conferences to formulate and codify rules of international law to govern the decisions of the World Court in all cases, except those involving any constituent State which has within the fixed period signified its dissent." ${ }_{3}$ One of the Recommendations of Havana suggested January 23, 1917, by the American Institute of International Law provides for "A stated meeting of The Hague Peace Conference, which, thus meeting at regular, stated periods,

1 Plan agreed on by the League of Nations Associations of the United States, Great Britain, France, Italy, and others. Boston Evening Transcript, Feb. 3, 1919.

2 Composed of delegates from sixty associations favoring a League of Nations. Boston Evening Transcript, May 13, 1919.

3 From platform of Feb., 1919, World Court. 
will become a recommending if not a law-making body." 1 The British League of Free Nations Association declared that "The Council of the League should . . . provide for the codification, amendment, and extension of international law." 2

One of the additions which Mr. Root proposed should have been made to the original draft of the Covenant was that "The Executive Council shall call a general conference of the powers to meet not less than two years or more than five years after the signing of this convention for the purpose of reviewing the condition of international law, and of agreeing upon and stating in authoritative form the principles and rules thereof." 3 "I believe," said Secretary of State Lansing, that the adoption of "an international code of principles for the guidance of an International Court of Justice is as essential as the creation of the court itself. . . . Let us draft a simple and concise body of legal principles to be applied to the questions to be adjudicated." " 4

Nothing is contained in the Covenant which gives to the Assembly the express power of agreeing on principles of international law. Article III provides that "The Assembly shall meet at stated intervals and from time to time as occasion may require. . . ." At these meetings it may deal with "any matter within the sphere of action of the League or affecting the peace of the world." And by Article XIX it may consider international conditions whose continuance might endanger the peace of the world.

It may be that the need for definite principles of international law will be so keenly felt that the members of the League will allow the Assembly to formulate principles

1 World Court, Aug., 1918, p. $475 . \quad 2$ Ibid., Nov., 1918, p. 673.

- See his letter to Mr. Hays, March 29, 1919, Am. Jl. Int. Law, July, 1919.

- From an address before the American Bar Association, Boston, Sept. 5, 1919. 
which to be binding would have to be ratified by the greater Powers. It is unlikely that the most powerful members of the League would feel an obligation to accept the recommendations of the Assembly unless they were allowed freedom of action in accepting those recommendations.

At any rate, there appears a vital need for a body which can agree on rules of international law. One of the reasons for the creation of the League is to achieve international peace by the firm establishment of the understandings of international law as the actual rule of conduct among Governments. Unless it is clearly known what these understandings are, it is obvious that one of the cardinal purposes of the League cannot be fulfilled. 


\section{H A P T E R I V}

THE INTERNATIONAL LABOR ORGANIZATION

The International Labor Organization created by the Covenant and treaty bids fair to make some contributions to international law. The permanent machinery of this organization is associated with that of the League of Nations (Article 427). The reason for such association is that peace can be established only if justice among the workers exists, "Whereas the League of Nations has for its object the establishment of universal peace and such a peace can be established only if it is based upon social justice " (preamble, Part XIII, Sect. I). The original members of the League are the original members of the labor organization (Article 392).

A General Conference of representatives of members of the League, chosen according to the stipulations of Article 389 , is held from time to time and at least once a year. The proposals of these conferences, determined by a twothirds vote of the delegates present, are referred back to the respective Governments in the form of recommendations to be made effective by national legislation or by ratification if the proposals are made in the form of draft conventions (Article 405). The members agree, within eighteen months, to bring the recommendations before the proper national authorities for action, but obligation ceases if such authorities fail to pass the necessary legislation or to ratify the draft convention. In the case of a federal State where constitutional limitations regarding draft conventions exist, such a convention may be treated as a recommendation so 
far as procedure is concerned. A member which refuses to refer the recommendations to the proper authorities of its Government makes itself liable to have the matter investigated by a Commission of Inquiry or to have it made the subject of a decision of the Permanent Court of International Justice (Articles 411, 416).

The, immediate contribution of the labor organization to international law is best shown by a consideration of the nine principles agreed on in Article 427.1 These are the first fundamental and authoritative principles regarding labor ever drawn up by an international conference. They are not yet, strictly speaking, principles of international law. They are principles which the members think "all industrial communities should endeavor to apply"; they are regarded as of "special and urgent importance" and as well fitted to "guide the policy of the League of Nations"; and finally, they are regarded as capable of conferring "lasting benefits upon the wage earners of the

1 These nine principles are:

1. The principle that labor should not be regarded merely as a commodity or article of commerce.

2. The right of association for all lawful purposes by the employed as well as by the employers.

3. The payment to the employed of a wage adequate to maintain a reasonable standard of life as this is understood in their time and country.

4. The adoption of an eight-hours day or a forty-eight hours week as the standard to be aimed at where it has not already been attained.

5. The adoption of a weekly rest of at least twenty-four hours, which should include Sunday wherever practicable.

6. The abolition of child labor and the imposition of such limitations on the labor of young persons as shall permit the continuation of their education and assure their proper physical development.

7. The principle that men and women should receive equal remuneration for work of equal value.

8. The standard set by law in each country with respect to the conditions of labor should have due regard to the equitable economic treatment of all workers lawfully resident therein.

9. Each State should make provision for a system of inspection in which women should take part in order to insure the enforcement of the laws and regulations for the protection of the employed. (Article 427.) 
world " (Article 427). It is highly probable that if a question arises which involves any of these principles, an international court will feel justified in recurring to them as the best indication of what the law is or ought to be. In the absence of other agreements between the members, what could be more authoritative or better fitted to guide a court than the recommendations of an international conference of delegates duly accredited by the Governments of the members of the League? 


\section{H A P T E R V}

\section{INTERNATIONAL LAW DURING THE WAR}

Applicability of the Hague Conventions. - It has often been said by those unfamiliar with the Hague Conventions that they were totally disregarded during the course of the war. Such a statement is only partially true. Some of the conventions were observed.

Convention IV of 1907 relating to "The Laws and Customs of War on Land" was not applicable during the war. Article 2 of this convention provides that the regulations shall not apply except between contracting Powers, and then only if all the belligerents are parties to the convention. Since several of the belligerents, notably Bulgaria and Turkey, had not ratified, it is clear that they were not parties to the convention, hence all the Powers which had ratified were released from their legal obligations; it was inapplicable because the condition necessary for its applicability was non-existent.

The rules of Convention II of 1899 did apply, however, for by Article 4 of Convention IV of 1907, it is expressly provided that "The Convention of 1899 remains in force as between Powers which signed it, and which do not also ratify the present convention." 1 All of the belligerents ratified the 1899 convention and it is for the violation of its provisions that the Versailles Treaty provides for the trial of certain Germans for breach of the laws and customs of war.

The provisions of Article I of Convention III of 1907

1 Scott, J. B., The Hague Conventions and Declarations of 1899 and 1907, p. 103. 
relating to the outbreak of hostilities were generally observed. It is provided that hostilities shall not begin "without previous and explicit warning, in the form either of a declaration of war, giving reasons, or of an ultimatum with conditional declaration of war. ${ }^{1}$ Neutrals were generally notified of the existence of a state of war as required by Article 2 of this convention.

Conventions V, VI, VII, VIII, IX, X, XI, XIII, of 1907, were legally inapplicable since each (Articles 20, $6,7,7,8,18,9$, and 28 , respectively) contained the following clause: "The provisions of the present convention do not apply except between contracting Powers and then only if all the belligerents are parties to the convention." 2 Morally, however, there existed upon all the signatories certain obligations to regard the humanitarian aims of the conventions. The moral obligation of today may, and often does become, the legal obligation of tomorrow.

Declaration XIV of 1907 prohibiting "the discharge of projectiles and explosives from balloons or by other new methods of a similar nature " ${ }^{3}$ was not binding on any of the belligerents because it was not ratified by Germany, France, Austria-Hungary and other belligerent Powers. They would be considered non-contracting Powers in the meaning of the clause providing that the Declaration "shall cease to be binding from the time when, in a war between the contracting Powers, one of the belligerents is joined by a non-contracting Power." "4 This same clause appears in Declaration IV of 1899 which was binding until the United States, which never ratified, joined the belligerents. This Declaration provides that " the contracting Powers agree to abstain from the use of projectiles the

1 Scott, p. $96 . \quad 2$ Scott, pp. 137, 142, 147, 152, 159, 172, 184, and 215.

$$
3 \text { Scott, p. 220. } 4 \text { Scott, p. } 221 .
$$


sole object of which is the diffusion of asphyxiating or deleterious gases." 1 It was violated before the belligerents were released from its legal obligation by the entrance of the United States into the war. Gases were used shortly after the outbreak of the war in 1914. This was one of the clearest breaches of the Hague agreements by Germany. The opposing side cannot be held for violation if the contract is broken by one party. Until the entrance of the United States into the war, Declaration IV of 1899 was binding upon the belligerents. It provides against the use of " bullets which expand or flatten easily in the human body, such as bullets with a hard envelope which does not entirely cover the core or is pierced with incisions." 2 Violations of this provision also occurred.

The belligerents were further bound by the preamble of Convention II of 1899 providing that " until a more complete code of the laws of war is issued, the high contracting parties think it right to declare that in cases not included in the Regulations adopted by them, populations and belligerents remain under the protection and empire of the principles of international law, as they result from the usages established between civilized nations, from the laws of humanity, and the requirements of the public conscience." 3

By Article 228 of the Treaty of Versailles the German Government recognizes the right of the Allied and Associated Powers to bring before military tribunals persons accused of having committed acts in violation of the laws and customs of war. Such persons shall, if found guilty, be subject to punishments laid down by the law. It is not clear just what punishments will be inflicted upon those found guilty. The commission charged with fixing the
1 Scott, p. 225.
2 Ibid., p. 227.
3 Ibid., pp. 101-108. 
responsibility for the war, of which Secretary of State Lansing was chairman, reported that it was desirable for the future that " penal sanctions should be provided for such grave outrages against the elementary principles of international law." 1 This article of the treaty and report by the commission constitute one of the strongest acknowledgments ever made of the validity of international law. Only the laws of war - not those of peace - were endangered by the war, and it was for violations of the laws of war that Germany received the condemnation of the world through its combined public opinion. That fact makes the outlook for the international law of the future very hopeful indeed.

The Trial of William II and the Sanctity of Treaties. Provision is made by Article 227 of the Versailles Treaty for the trial of William II of Hohenzollern " for a supreme offense against international morality and the sanctity of treaties," the decision to be based on the highest motives of " international policy with a view to vindicating the solemn obligations of international undertakings and the validity of international morality." The extent to which this provision upholds and strengthens international law is made clearer by a brief consideration of what is meant by the sanctity of treaties in this particular case. By the treaties of 1831 and 1839, Germany agreed to respect the neutrality of Belgium. On January 7, 1871, Germany joined in the following declaration: "The plenipotentiaries of North Germany, of Austria-Hungary, of Great Britain, of Italy, of Russia, and of Turkey, meeting today in conference have agreed that it is an essential principle of the law of nations that no Power can unbind itself of the

1 Quoted by Mr. Lansing in an address before the American Bar Association, Boston, Sept. 5, 1919, Boston Evening Transcript, Sept. 5, 1919. 
obligations of a treaty or qualify its stipulations, except with the consent of the contracting Parties by way of an amicable agreement." 1 This declaration was, of course, applicable to the treaties guaranteeing the neutrality of Belgium.

Article I of Convention V of 1907 was ratified by Germany, and while, as noted above, it was not binding legally, it nevertheless was binding morally. It is a statement of the principle which all nations ought to respect even in the absence of a special agreement, that neutral territory should be respected by belligerents. "When," said former Secretary of State Root, "we recall Mansfield's familiar description of international law as 'founded upon justice, equity, convenience, the reason of the thing, and confirmed by long usage,' we may well ask ourselves whether that general acceptance which is necessary to the establishment of a rule of international law may be withdrawn by one or several nations and the rule be destroyed by that withdrawal so that the usage ceases and the whole subject to which it relates goes back to its original status as matter for new discussion as to what is just, equitable, convenient and reasonable." "2 It was with some of the considerations mentioned above in his mind, that President Wilson declared that "Belgium, the whole world will agree, must be evacuated and restored. . . . Without this healing act the whole structure and validity of international law is forever impaired." 3

The Covenant itself is calculated to strengthen that principle of international law which recognizes the sanctity of treaties. It provides (Article XVIII) that every treaty

1 British Foreign State Papers 61, pp. 1198-1199.

2 "The Outlook for International Law," World Peace Foundation, Vol. VI, No. 3. June, 1916. An address before the American Society of International Law, Dec. 28, 1915.

3 Italics mine. 
or international engagement entered into by any member of the League must be immediately registered with the Secretariat, and that no such agreement is binding until so registered. The Assembly may advise the reconsideration by members of the League of treaties which have become inapplicable; this provision will prevent the existence of a great many obsolete, confusing treaties. One of the chief causes for the breach of treaties in the past has been the desire for selfish gain or for conquest. Many treaties which might be conducive to such desires will be abrogated under Article XX of the Covenant which provides for the abrogation of all obligations or understandings existing among the members of the League which are inconsistent with the terms of the document itself. The members likewise agree not to enter into such understandings in the future. It is also made the duty of any member which, before becoming a member, undertook an obligation inconsistent with the terms of the Covenant, to take immediate steps to secure its release from such obligations (Article XX, 2). 


\section{H A P T E R V I}

IN CERTAIN CASES WAR MADE AN ILLEGAL PROCESS BY THE COVENANT

“Today,” said Premier Lloyd George, "we are waging the most devastating war the world has ever seen. Tomorrow, tomorrow, not perhaps distant tomorrows, war may be abolished forever from the category of human crimes." 1 Former Secretary of State Knox likewise suggested in the Senate that an International League embracing all nations should be formed and one of the provisions of its constitution should declare that "war is to be an international crime and that any nation engaging in war, except in self-defense when actually attacked, shall be punished by the world as an international criminal." 2 The distinguished Belgian Professor of international law, Henri La Fontaine, urged in 1917 that as a new principle of international law "war should no more be considered as a legal institution, because it is a crime and should be considered as such." ${ }_{3}$ Theodore Marburg, former United States Minister to Belgium, urged the adoption of a similar principle. "Society," he said, " implies restraint. We can have no liberty without a surrender of license. The one license which it has become perfectly clear the nations must surrender is the license to make war at will." 4

1 Quoted by Congressman James L. Slayden of Texas from a speech delivered by Mr. Lloyd George in London. Annals Am. Acad. Pol. and Soc. Sci., July, 1917, p. 101.

2 Speech in the United States Senate, March 3, 1919, Boston Evening Transcript, March 3, 1919.

3 "On What Principles is the Society of States to be Founded?" Annals Am. Acad. Pol. and Soc. Sci., July, 1917, p. 90.

" "Sovereignty and Race as Affected by a League of Nations," Ibid., p. 143. 
Just how far does the Covenant actually illegalize war? By the preamble the high contracting parties accept "obligations not to resort to war" in order that international coöperation may be promoted and international peace achieved. They then recognize (Article VIII, 1) that the maintenance of peace requires the reduction of armaments to the lowest point consistent with national safety and the enforcement by common action of international obligations. The provisions of Article VIII are corollary to those of Article $\mathrm{X}$ which illegalize wars of conquest or external aggression, leaving the members of the League to be concerned only with their own national safety and with their international obligations. In order to realize the ends set forth in the preamble and in Articles VIII and X, the members of the League condemn the manufacture by private enterprise of munitions and implements of war and establish a permanent commission (Article IX) to supervise the reduction of armaments. They also declare that any war or threat of war is a " matter of concern to the whole League" (Article XI).

With the exception of Article X, the above considerations do not specifically illegalize war, but they show that the whole spirit of the Covenant is to prevent war; they deal mostly with preventive means.

In a question submitted to arbitration or to inquiry the members agree " in no case to resort to war until three months after the award by the arbitrators or the report by the Council" (Article XII). But if the report by the Council is unanimous, excluding disputants, the members agree " that they will not go to war with any party to the dispute which complies with the recommendation of the report" (Article XV, 6). As regards disputes submitted to arbitration, the members agree (Article XIII, 4) that they will 
not resort to war against any member which complies with the award. Since by Article XII the members agree to submit, either to arbitration or inquiry, "any dispute likely to lead to a rupture," it is clear that war is illegalized in the cases considered. These cases may be summarized as follows:

1. A war of conquest or external aggression is illegal;

2. A war resorted to by one member after the matter in dispute has been the subject of an arbitral award which is complied with by the other disputant, is an illegal war;

3. A war is illegal if resorted to by a member in disregard of a unanimous recommendation by the Council (excluding disputants) which is complied with by the other disputing member;

4. All wars between members of the League are illegal if begun before a delay period of from three to nine months has elapsed.

It is agreed (Article XVI, 1 ) that if a member resorts to war in "disregard of its covenants under Articles XII, XIII, or XV, it shall ipso facto be deemed to have committed an act of war against all other members of the League," and shall be liable to the consequences laid down in that article. The League may resort to war, as an ultimate sanction to uphold the agreements made by members who have pledged themselves not to go to war in certain cases. This is not war in the old sense; it is an exercise of the combined police power of the League against members who have agreed in advance to make themselves liable to this police power. The exercise of this power by the League is authorized only to uphold and protect the Covenant the underlying spirit and tenor of which is to prevent war and to make it illegal. It is, in accordance with the recommendation of the French Association for the Society of 
Nations of which Léon Bourgeois is Honorary President, a "use of force reserved exclusively to the international society itself " used as a " supreme sanction." 1

In discussing the Amphictyonic Council the German writer Tittman in $1812^{2}$ raised the point made first by Montesquieu ${ }^{3}$ that there was an inconsistency in each member of the council agreeing not to destroy any Amphictyonic city and yet when the whole council acted together it might destroy a city which had violated the agreements of the council. Tittman answers this objection by saying that there is no inconsistency ("kein Widerspruch") in doing through the common power ("gemeinschaftliche Macht") what is forbidden to each individual; that in municipal law the State punishes the individual citizen ("Einzelnen Bürger") while self-help is denied to that individual. He points out further that the council proceeded against non-members as well as members.

The distinction between that which the League acting as a whole may do, and that which an individual member acting by itself may do, is fundamental. Again the actual provisions of the Covenant are in harmony with the recommendation of a great American authority. "Assuming," he said, "that our goal is the establishment among nations of a reign of law in such sense that each nation is subject to the law, the fundamental object which it is essential to accomplish is to limit the present unrestricted right of the individual nation to declare war and incidentally to acquire the right of conquest." "4

1 World Court, Nov., 1918, pp. 670-671.

2 Tittman, F. W., Bund der Amphiktyonen, p. 226. (Berlin, 1812.)

${ }^{3}$ De l'esprit des lois, Liv. XXIX, ch. 5 .

4 Moore, John Bassett, “International Coöperation,” World Court, Jan., 1916, p. 273; italics mine. 


\section{CHA P T E R VII}

\section{SETTLEMENT OF DISPUTES}

“The League of Nations," said Premier Lloyd George, "represents the greatest attempt which ever has been made to substitute reason and justice for force and intrigue as the governing principle of international relations." 1

The Permanent Court of International Justice. - In accordance with Article XIV of the Covenant the Council of the League of Nations has appointed a group of distinguished jurists and authorities on international law, ${ }^{2}$ to formulate plans for the establishment of a Permanent Court of International Justice. This court shall be competent to hear any dispute of an international character that the disputants submit to it. It may also give an advisory opinion upon any question or dispute referred to it by the Council or by the Assembly. The name of the court is significant. It is not a court of arbitration similar to that established at The Hague in 1899 and continued in 1907. Nor is it a Judicial Arbitration Court which was contemplated by the draft convention annexed to the first voeu of the second Hague Conference, ${ }^{3}$ although that project may well be used as a basis for the new court. The proposed court is to be a true court of international

1 Manchester Guardian, Dec., 29, 1918.

2 Announced at meeting of the Council held at London, Feb. 13, 1920. Among the group are: Elihu Root; Baron Phillimore, formerly lord justice of appeal, Great Britain: Henri Fromageot, prominent advocate, France; Baron Deschamps, member of permanent court of arbitration at The Hague, Belgium; Professor Gran, University of Christiania, Norway; Professor Fadda, University of Naples, Italy; and Clovis Bevilacqua, authority on international law, Brazil. (League of Nations Journal, March, 1920.)

3 Scott, J. B., The Hayue Conventions and Declarations of 1899 and 1907, p. 31. 
justice which means that it ought to decide questions according to international law rather than on grounds of compromise or expediency as may properly be done by a tribunal of arbitration.

The Permanent Court of International Justice will serve as a court of appeal (Article 418) from the report of the commission of inquiry constituted according to Article 412 of the Versailles Treaty, to deal with disputes relating to labor. It may vary, affirm or reverse any of the findings or recommendations of the commission of inquiry, if any, and in its decision indicate what measures, if any, of an economic character which it considers to be appropriate, and which other Governments would be justified in adopting against a defaulting Government (Article 418). But if a member fails to abide by the recommendation of the commission of inquiry or the decision of the court, the use of the economic sanction recommended by the court is to be optional for the other members (Article 419). When the defaulting Government considers that it has met the conditions of the decision of the court, it may apply to the Secretary-General of the League to constitute a new commission of inquiry to determine whether or not the conditions have been met, and if so, the economic measures against the defaulting Government cease (Article 420). Such measures likewise cease if the court finds that its decision has been satisfactorily followed.

It is thus seen that the Permanent Court of International Justice is empowered to advise the use by the members of the League of economic sanctions to enforce its decisions; military and naval force is not contemplated. This is true only of its labor decisions, however. If a decision is rendered according to the provisions of Article XIII of the Covenant, all of the sanctions of Article XVI, including military, 
naval and air forces, will be applicable as against a recalcitrant member, provided the Council so recommends, and the other disputant accepts the decision of the court.

Justiciable and Political Questions. - The Covenant does not distinguish between arbitration and adjudication. It has been generally understood that these processes, in the strict sense, are, and ought to be distinguished. To submit a matter to arbitration has generally conveyed the idea that the board or tribunal of arbitration would determine the question, if necessary, by compromise or on grounds of expediency. This does not mean, however, that the law is not considered; it may be regarded by the board or tribunal, and the award may be made entirely or largely according to strict principles of law. When, however, the dispute is one susceptible of adjudication by a court of justice which applies only legal principles, a distinction should be made between such adjudication, and arbitration which may involve the element of compromise. The term "conciliation" is often applied to the method of settling disputes which are of a purely political nature.

It is true that the Permanent Court of Arbitration set up at The Hague in 1899 and continued in 1907 has settled disputes which were susceptible of determination according to strict principles of law, as for example, the Pious Fund case, $^{1}$ and the Japanese House Tax case. ${ }^{2}$ It has also decided cases on grounds of compromise and expediency, as, for example, the case of the Deserters at Casablanca. ${ }^{3}$ It is presumed that this court will be continued. Boards of arbitration for the settlement of industrial questions have become so common that it seems essential to reserve

1 Wilson, G. G., The Hague Arbitration Cases, pp. 1-11.

2 Ibid., pp. 40-63.

Ibid., pp. 82-101. 
the term "adjudication" for that process of settling disputes according to strict legal principles which are principles of justice not susceptible of compromise.

The difference between justiciable and political questions has been pointed out repeatedly by the Supreme Court of the United States. Among the questions decided by that court to be political are: ${ }^{1}$ the relation of an Indian tribe to a State, Cherokee Nation $v$. Georgia (1831), 5 Peters, 1; the President of the United States is sole judge as to when the militia should be called out, Martin $v$. Mott (1827), 12 Wheaton, 19; the recognition of the belligerency or independence of a foreign community, The Three Friends (1897), 166 U. S., 1; and whether a treaty with another nation has been properly ratified by that nation, Doe $v$. Braden (1854), 16 Howard, 635. These questions the court has called political, and has studiously avoided passing upon them. The following distinction between political and judicial questions was made by the court in Rhode Island $v$. Massachusetts (1838), 12 Peters, 737, Mr. Justice Baldwin delivering the opinion:

"These considerations lead to a definition of political and judicial power and questions; the former is that which a sovereign or State exerts by his or its own authority, as reprisal and confiscation; ... the latter is that which is granted to a court or judicial tribunal. So of controversies between States; they are in their nature political, when the sovereign or State reserves to itself the right of deciding on it; makes it the 'subject of a treaty to be settled as between States independent,' or 'the foundation of representation from State to State.' This is political equity,

1 Other cases in which judicial and political questions are differentiated are: Foster v. Neilson (1892), 2 Peters 253; Luther v. Borden (1849), 7 Howard 1; and Mississippi v. Johnson (1866), 4 Wall. 475. 
to be adjudged by the parties themselves, as contradistinguished from judicial equity, administered by a court of justice, decreeing the equum et bonum of the case, let who or what be the parties before them."

The first plank in the platform of the League to Enforce Peace provides that all " justiciable questions arising between the signatory Powers not settled by negotiation, shall, subject to the limitation of treaties, be submitted to a judicial tribunal for hearing and judgment." ${ }^{1}$ Likewise the Bryce group of Great Britain distinguished between "disputes . . . which are of a justiciable character" and other disputes of a political nature. ${ }^{2}$ The best examples of questions which are justiciable are those relating to the interpretation of treaties and those relating to international law, the assumption being that the law cannot be compromised or evaded in its application to questions of this nature. The rules for the interpretation of treaties or the law of inviolability which protects an ambassador's person and premises cannot be compromised; they are fixed, and must be strictly applied.

The framers of the Covenant have divided disputes into three categories: those capable of settlement by diplomacy (Article XIII); those recognized as suitable for submission to arbitration (Article XIII); and those which are likely to lead to a rupture and which do not come within the first two categories (Article XV). The first class of disputes will continue to be settled by the give-and-take methods of diplomacy. The second class are, according to Article XIII, 2 of the Covenant, those questions which have usually been called justiciable questions, but here are called questions "generally suitable for submission to arbitration." It is

1 World Peace Foundation, pamphlet, Vol. VI, No. 5, Oct., 1916.

2 Woolf, L. S., The Framework of a Lasting Peace, p. 18. (London, 1917.) 
thought that these questions will always be submitted to the Permanent Court of International Justice.

The definition of justiciable questions given in paragraph 2 of Article XIII of the Covenant, is due to Elihu Root. In a letter to Mr. Hays, March 29, 1919, he recommended the inclusion of the following paragraph in the revised draft of the Covenant:

"Disputes of a justiciable character are defined as disputes as to the interpretation of a treaty, as to any question of international law, as to the existence of any fact which if established would constitute a breach of any international obligation, or as to the nature and extent of the reparation to be made for any such breach."

The members of the League determine for themselves what questions (in addition to justiciable questions which are always submitted) shall be submitted to arbitration (Article XIII, 1). It is possible that questions which may be partly political and partly justiciable will be referred to the permanent Court of Arbitration at The Hague. Such questions are called by Professor Oppenheim “ complex cases which are justiciable but in which, besides the question

1 This definition appears in about the same form in Section 20 of the Smuts' Plan. Mr. Marburg has called the author's attention to the fact that the same wording appears in the Proposals for the Avoidance of War published by the Bryce Group, Feb. 24, 1915. It is likely that the prominence given to the definition by Mr. Root caused it to be inserted in the Covenant.

By permission the following letter from Lord Bryce to Mr. Marburg relating to the origin of the definition of a justiciable dispute is given:

Mt dear Mr. Marburg:

"3 Buckingham Gate, LoNDoN, S. W.

After consulting a friend who worked with me on the small British Committee which prepared the "Proposals for the Avoidance of War" I find that the words you refer to as defining 'disputes of a justiciable character' were settled by us as the definition we thought most clear and complete and were not, so far as I know, taken bodily from any other source. My belief is that we composed this definition after reading others, but that, in the shape we gave it, it was our own. 
of law, there is at the same time involved a vital political principle or claim." 1 Settlement of political disputes is reserved to the Council to be decided by conciliation. Compromise and expediency will govern the determination of these questions. The Council will, however, be expected to respect the law so far as that is possible. If the dispute is referred to the Assembly, the same principles which apply to the reports of the Council will govern.

1 L. Oppenheim, in an opinion regarding the proposed Court of International Justice, World Court, Feb., 1918, p. 75. 


\section{H A P T E R V I I I}

SOME MODIFICATIONS IN THE THEORY OF INTERNATIONAL LAW

"The press, which reaches millions of Americans, must help break down the international law," said Henry Morgenthau, former United States Ambassador to Turkey, "which says no nation can interfere with the internal affairs of another nation. Whenever I tried to intercede for the oppressed people in Turkey I was told that it was none of America's business." 1

The conceptions of international law which have been considered in the preceding pages have, with the exception of the last-considered conception under the League of Nations, been based upon the assumption that every nation is sovereign and independent, with its own interests entirely separate from those of other nations. No sovereign nation could in any way interfere in the affairs of another nation except in certain cases where its own special interests were endangered. ${ }^{2}$ Hall holds that intervention is illegal except " for the purpose of self-preservation, unless a breach of the law as between states has taken place or unless the whole body of civilized states have concurred in authorizing it." ${ }^{3}$ The collective intervention in China in 1900, to suppress the Boxer uprising and protect the legations, is the best example of combined action by several nations.

"In the society of nations," said Professor Munroe

1 World Court, Aug., 1918, p. 475.

2 Wilson and Tucker, International Law, p. 87. (7th ed., 1917.)

3 International Law, sect. 92. (7th ed. by Higgins, 1917.) 
Smith, "the redress of an international wrong by the concerted action of a number of states is a significant step. . . . In the development of tribal law, such reactions indicated that offenses previously regarded as torts were beginning to be viewed as crimes. Concerted action by the society of nations against an offending state seems to imply a recognition that a state may be held accountable, not only to other single states which it has directly injured, but also to the world for a crime against civilization." 1 "If," said Mr. Root, "the law of nations is to be binding, . . . there must be a change in theory, and violations of the law of such a character as to threaten the peace and order of the community of nations must be deemed to be a violation of the right of every civilized nation to have the law maintained and a legal injury to every nation." 2

Several clauses of the Covenant actually apply the change in the theory of international law which Professor Smith and Mr. Root had in mind. Article $\mathrm{X}$ gives the members of the League the right to intervene in case the territorial integrity or political independence of one of their number is endangered or violated by outside aggression. Articles III, 3, and IV, 4, give the Assembly and Council respectively, the competency to deal with " any matter . . . affecting the peace of the world" and within the sphere of action of the League. Article XI, 1, makes any war or threat of war a "matter of concern to the whole League." Article XI, 2, makes it the friendly right of each member to bring to the attention of the Council or the Assembly "any circumstance whatever affecting international relations which threatens to disturb international peace or the good

\footnotetext{
1 “The Nature and Future of International Law," Presidential address, Amer. Pol. Sci. Association, Am. Pol. Sci. Rev., Feb., 1918, p. 1.

2 “The Outlook for International Law," Presidential address, Am. Soc. International Law, Washington, Dec. 28, 1915.
} 
understanding between nations upon which peace depends." In view of these provisions Francis Lieber could not write in a war code today, that "the law of nations allows every sovereign government to make war upon another sovereign state." 1 The theory of absolute and unlimited sovereignty of nations must be so far modified as to make it fall into harmony with the actual relationship between nations as it is established by the Covenant. The members limit their sovereignty in regard to making war. It cannot be too strongly emphasized that any action of intervention is taken by the League acting as a unit. If it intervenes at all, it will do so only when a condition arises which falls within the category of matters which the members have agreed in advance that the League might act upon.

Neutrality. - The second of President Wilson's fourteen points declared that there must be " absolute freedom of the seas in peace or war except as they may be closed by international action." This conception was formed before the League of Nations had been much discussed; it contemplated the world in the old condition when there was no concerted action and each nation acted for itself. Upon arriving at Paris, however, President Wilson himself admitted that he would have to throw overboard this point because under the League there would be no neutrality. ${ }^{2}$ Not the question of freedom of the seas alone, but those concomitant questions such as contraband and continuous voyage are affected by the abolition in certain cases of neutrality. The essential condition necessary for freedom of

1 U. S. Army, General Orders, No. 100 (1863), Art. 67.

${ }^{2}$ G. S. Adam (London Times-Public Ledger Cable Service), Boston Evening Transcript, Feb. 26, 1919: "President Wilson recently remarked to a group of American journalists, that when he placed the question of the freedom of the seas among the fourteen points it never struck him that under the League there would be no neutrals and that consequently the question of neutral rights would not arise." 
the seas is the allowing of private property to move on the seas in time of war as in time of peace. This of course involves the question of contraband. By Article XVI of the Covenant the members agree that they will " mutually support one another in resisting any special measures aimed at one of their number by the covenant-breaking member ... and to afford passage through their territory to the forces of any members of the League which are coöperating to protect the covenants of the League." This means that freedom of passage will be given in territorial waters as well as over land. No question as to landing at neutral ports in the course of a continuous voyage, or of the violation of neutral territory by the passage of belligerent troops, would arise. Each member of the League has, by agreeing to Article XVI, surrendered its right to remain neutral, in so far, at least, as economic, financial and trade sanctions are concerned. It must abide by its agreement to employ these sanctions. The military, naval and air forces are furnished by each member at discretion, but neutrality is destroyed by the use of the other sanctions.

It is seen by this examination that certain attributes of sovereignty formerly possessed by each member of the League as it stood aloof from all others, have been voluntarily transferred or delegated to the organs of the League. The most important of these are: the right of conquest; the right to make war at will; and the right in all cases to remain neutral. The general change effected by the Covenant is thus expressed by Dr. Quincy Wright, a leading younger student of international law:

". . . The Covenant when put into operation will modify international law, though less in its specific rules than in certain assumptions upon which they have heretofore been supposed to rest. 


\section{THE NEW INTERNATIONAL LAW}

"By accepting the league, states recognize that their existence depends upon the general maintenance of law, and consequently that they must prefer the claim of that law for defense, as against the lure of an immediate national profit. Thus, though international law will continue to aim at preserving the independence and autonomy of states, it must assume its own preservation is more important. It follows that international law can no longer be conceived by text writers as a series of deductions from an assumed 'fundamental right of states to exist.' The responsibility of states to assure the existence of the law will have to be conceived as even more fundamental. . . .

“ . . . The Covenant recognizes that states cannot survive where sovereignty can override the law. As the price of existence, states must accept definite responsibilities for the maintenance of law. Should this conception, about to be formally accepted, become instinctive in our civilization, the time might come when the chapters on war and neutrality, which overburden textbooks on the law of nations, could be relegated to historical appendices." 1

The peculiar status of Switzerland as a permanent neutral is continued under the League. The Versailles Treaty (Article 435) recognizes that the new régime established by the League of Nations creates a situation in which the old guarantees in Article 3, paragraph 2, of the Treaty of Paris, 1815, and Article 92, paragraph 1, of the Final Act of the Congress of Vienna "are no longer consistent with present conditions." Note is taken of the agreement reached between the French and the Swiss Governments "for the abrogation of the stipulations relating to this zone [Savoy] which are and remain abrogated."

1 "Effects of the League of Nations Covenant," American Pol. Sci. Review, Nov., 1919, pp. 556, 557, 565. 


\section{THE LEAGUE OF NATIONS}

But "the high contracting parties ... recognize the guarantees stipulated by the treaties of 1815 , and especially by the Act of 20th November, 1815, in favor of Switzerland, the said guarantees constituting international obligations for the maintenance of peace. . . ." 1

Switzerland made clear that she understands that the signatories to the Versailles Treaty supersede the signatories to the treaties of 1815, as guarantors of the neutralized zones. In a note to the French Government, May 5, 1919, which is incorporated into the annex to Article 435 of the treaty, the Swiss Federal Council declared that " the assent given by the Swiss Government to the abrogation of the above-mentioned stipulations presupposes, ${ }^{2}$ in conformity with the text adopted, the recognition of the guarantees formulated in favor of Switzerland by the treaties of 1815 and particularly by the declaration of 20th November, 1815." 3

1 Versailles Treaty, Article 435.

2 Italics mine.

3 In acceding to the League Switzerland agreed to employ the economic sanction required in Article XVI. 


\section{H A P T E R IX}

\section{THE QUESTION OF SANCTIONS}

ThE League of Nations establishes the central authority that was lacking in the structure of The Hague. The Covenant provides that the Council of the League shall recommend what action shall be taken to give effect to arbitral awards and unanimous (excluding disputants) reports by the Council itself.

As early as 1910, Mr. Roosevelt suggested some such arrangement as that actually adopted in the Covenant. "It would be a master stroke," he said, "if those great powers honestly bent on peace would form a League of Peace, not only to keep the peace among themselves, but to prevent, by force if necessary, its being broken by others. The supreme difficulty in connection with developing the peace work of The Hague arises from the lack of any executive power, to enforce the decrees of the courts." 1 No less forcefully has Mr. Root expressed a similar conviction. "Laws," he said, "to be obeyed must have sanctions behind them; that is to say, violations of them must be followed by punishment." After referring to force as a sanction he describes the potency of public opinion because " of the terrible consequences which come upon a nation that finds itself without respect or honor in the world and deprived of the confidence and good-will necessary to the maintenance of intercourse." 2

1 Nobel Peace Prize address, Christiania, Norway, May 5, 1910.

2 Presidential address, "The Outlook for International Law," delivered before the American Society of International Law, Washington, Dec. 28, 1915. 
An analysis of the question of sanctions shows that two schools of thought existed before the adoption of the Covenant, as to what constituted the most feasible and most effective sanction. One school stressed force as the ultimate sanction. Mr. Taft and the League to Enforce Peace of which he is the President, may be identified with this school. Mr. Roosevelt would belong to this group. The other school stressed the potency of public opinion as the final sanction. Lord Robert Cecil and Dr. James Brown Scott might be classed as leading exponents of this view. It would not be safe to assume, and is not assumed, that the exponents of the sanction by force disregard the power of public opinion. They do not. They believe that while force may be kept in the background while the League is young, it may be possible after the League has established itself as an institution of justice and law, to allow public opinion gradually to replace force as a sanction.

Another sanction which had received considerable attention before the adoption of the Covenant was the economic boycott which was first suggested by Mr. Carnegie in 1907. "If," he said, " instead of an international police force, the nations would agree to cease commercial relations with any Power breaking the peace, this punishment might prove equally effective. No interchange of products, no supplying of war materials or loans, no mails, would be a severe rebuke, carrying with it as well material loss. The more peaceful punishment might first be applied and military force held in reserve, to be resorted to only when all other measures failed." 1

The third article of the program of the League to Enforce

1 From an introduction by Mr. Carnegie to Hayne Davis's, Among the Worlds Peacemakers. (New York, 1907.) 
Peace, the essential features of which are incorporated into Article XVI of the Covenant, was introduced by President Lowell of Harvard. ${ }^{1}$ As formulated by Doctor Lowell the article provided that the "signatory Powers shall jointly use forthwith both their economic and military forces against any one of their number that goes to war or commits acts of hostility against another of the signatories before any question arising shall be submitted to arbitration." 2

The French League of Nations Society proposed a juridical sanction, which would deny the use of the courts to nationals of a recalcitrant Power. The limited number of persons to which this prohibition would apply, however, makes it less effective than the sanctions actually adopted.

Turning now to the Covenant itself, let us see what application of the theories of sanctions is made. Without doubt, sanction by public opinion was regarded by the framers of the Covenant as one of its most powerful backing forces. The spirit of the preamble shows this. The members are to strive for open, just and honorable relations between nations. International law which is based largely on the public opinion of the world, is made the "actual rule of conduct among Governments." Treaty obligations are to be scrupulously respected. The reports by the Council on non-justiciable questions are intended to meet the demands of public opinion.

If public opinion should fail, the members of the League agree by Article XVI, 1, to sever " all trade or financial relations," and to prohibit " all intercourse between their nationals and the nationals of the covenant-breaking member" as well as the prevention of all financial, commercial,

1 See Dr. Lowell's letter to Senator Walsh of Massachusetts, dated Dec. 31, 1919 , Boston Evening Transcript, Jan. 9, 1919.

2 Ibid. 
or personal intercourse between the nationals of the covenant-breaking member and the rest of the world. These are indeed powerful weapons; a nation will think seriously before making itself liable to such consequences. But if these measures prove ineffective, it becomes the duty of the Council, as a last resort, to recommend the quotas of military, naval or air forces necessary from each member to uphold the agreements in the Covenant.

It is thus seen that the three sanctions regarded as the most effective are provided for in the Covenant. The relation of these sanctions to the success of the League and to future international law is very close. The development of the law will largely depend upon the manner in which the members regard and respect the sanctions of the League. Those sanctions will make the League that international authority for which the world has long been in wait; they will make the League a real instrument of international law. As M. Léon Bourgeois, the French representative on the Council said at the plenary session of the Peace Conference, January 25, 1919: "The second difference between that time [the time of the Hague Peace Conferences] and the present time is that you will be able to sit and establish a system of sanctions. . . . At The Hague it was impossible because of the division between the nations there. . . . At present wc are in a position not only to lay down principles but also to establish a system of penalties." 1 No longer can it be said as Professor John Bassett Moore, one of America's foremost authorities on international law, felt it necessary to say in 1906, that " the most striking imperfection in the international system today is the lack of a common agency for the enforcement of law." 2

1 New York Times, Current History, March, 1919, p. 387.

2 The Independent, July 5, 1906. 


\section{H A P T E R X}

THE JUdicIal STATUS OF THE LEAGUE OF NATIONS

Sovereignty. - "If," said L. Duguit, the eminent French writer, "there is such a thing as sovereignty of the State it is juridically limited by the rule of law." 1 Two important points are here suggested by M. Duguit. First, the expression of a doubt as to whether there is such a thing as sovereignty; and second, that if there is, it cannot override, or prevail over, the rule of law.

It cannot be denied that there is a thing called sovereignty. As in case of all abstract ideas, however, there is difficulty in defining precisely what is meant when one speaks of sovereignty. It is by Wheaton called "the supreme power by which a State is governed." 2 This definition is concise, and expresses the same idea that is expressed by numerous longer and more involved definitions. It is more comprehensive than the definition that sovereignty is that power which makes and enforces the laws of a State. It best adapts itself to the conception of international law and of international relationship under the League of Nations. Sovereignty is more than that power which makes and enforces laws within a State; it also includes the powers of making treaties and conducting the foreign relations of a State. Thus a gentlemen's agreement may be made between two States, and while such an agreement would not be law, it would be the result of an exercise of the supreme power by which a State is governed. The

1 L'Etat; Le Droit Objectif et la Loi Positive, ch. 1, p. 247.

2 Elements of International Law, 8th ed., p. 31. 
gentlemen's agreement which exists between the United States and Japan regarding immigration, is an example of an exercise of the powers of sovereignty in an external way, facing outward, as contradistinguished from a federal law made and enforced within the United States, that is, facing inward. In the tenth of his Studies in History and Jurisprudence, Lord Bryce distinguishes between internal sovereignty belonging to the organs of government to which the people of the State delegate sovereign powers, and external sovereignty which remains vested in the whole people itiself. The Bryce conception of external sovereignty is practically the same as that of Wheaton, who believed that " external sovereignty consists in the independence of one political society in respect to all other political societies." 1

The conception of sovereignty as an indivisible whole has generally given way to the conception that the governmental powers of sovereignty, but not the supreme will itself, may be divided. Thus the tenth amendment to the Constitution of the United States divides the powers of sovereignty into those delegated to the United States, and others, not prohibited to the States, but reserved to them respectively, or to the people. As regards other nations, the sovereignty of the United States is expressed only by those federal officials who represent the American people. ${ }^{2}$

It is with sovereignty in its external aspect that the League of Nations has to do. The League, by Article XV, 8, of the Covenant, is not permitted to deal with questions which by international law are solely within the domestic jurisdiction of one of the member States. It has been shown that the members of the League, upon joining that organization, surrendered or delegated to the League itself, three

1 Ibid., p. 32.

${ }^{2}$ Cf. Munro, W. B., Government of the United States, pp. 392-394. 


\section{THE NEW INTERNATIONAL LAW}

attributes or powers of sovereignty which they possessed before they became members, viz., the right in all cases to remain neutral; the right of conquest; and the right to make war at will. It will be noted that each of these socalled rights has to do with sovereignty in its external aspect; they are juridically limited by rules of international law laid down in the Covenant itself.

State. - The word "State" as used in the international sense connotes a definite and particular territory together with the people who dwell thereon. The government of the State embraces the human instrumentalities by which the people are kept in a state of reasonable happiness and order, and by which their relations with the people of other States are conducted. It is conceivable that the whole personnel of a government might temporarily continue to govern the people of a State, and yet be absent from the territory; or that the government might exist without any territory at all. In the usual sense, in order that there may be a State, there must be a government for that State, and in order that there may be a government, there must be a State to be governed. In view of the accepted conception of a State and of the express and limited powers given to the organs of the League of Nations, the idea that the League is a super-State may be dismissed as entirely without foundation.

Confederation. - A confederation of States, in the accepted sense, is a union of independent, sovereign States for the purpose of preserving their external, as well as their internal, independence. The Germanic Confederation, 1815-1866, is an example of a loose organization which has been found in most confederations. Article 2 of the Act of May 15, 1820, which completed the Act of 1815, establishing this confederation provided that it was a "self-subsisting 
Association of States, mutually independent of one another, with equal reciprocal rights and obligations; but, in its external relations, a collective power combined in political unity." 1 Here, as has been the case in all true confederations, the independence of the members is emphasized. The chief reason for the failure of the government of the United States under the Articles of Confederation was that the members attempted at the same time to retain their independence and to present to the world a unified central government capable of dealing with other States of the family of nations. It is well known how the European Powers were unable to deal with ministers from thirteen American States.

The League of Nations can hardly be called a confederation. The fact that the lesser Powers are not admitted on the same footing as the great Powers, shows that the degree of independence and the equality which has usually been found in confederations, are lacking in the case of the League. Moreover, the League has no control over the individual members, in so far as the powers and functions of government are concerned.

Alliance. - An alliance is merely an agreement between two or more States to act together according to the terms of the treaty of alliance, when the conditions contemplated by that treaty shall arise. No organs of government or administration are found in such unions.

In view of the three organs set up by the Covenant, it is clear that the League cannot correctly be called an alliance.

Equality. - In order to determine the nature and status of the League, it is necessary to examine what application is made by the Covenant, of the principles of equality.

1 Phillimore, International Law, I, p. 161. 
The ranking delegate of Great Britain to the second Hague Peace Conference of 1907 stated that one of the chief obstacles to progress in the conference was the question of equality. The small States demanded equal representation with that of the great Powers. The failure to establish the Judicial Arbitration Court was due to the inability of the conference to agree on a method of representation on the court which was acceptable to the smaller States. The problem of selection of judges was solved with respect to the International Prize Court, however, by an ingenious system of rotation. The eight great Powers, viz., the United States, Austria-Hungary, France, Great Britain, Japan, Germany, Italy, and Russia, were always to have judges on the court. The system of rotation provided that the remaining seven judges of the court were to be allotted to the lesser Powers for periods ranging from one to four years of the six-year period for which all judges were chosen. The period for which the lesser Powers appointed judges bore some relation to their general importance in the community of States. Thus Spain was entitled to a judge four years in the six-year period; the Netherlands was to be represented for three years; and Bulgaria, Portugal, and Venezuela were to have judges one year only.

The method of selecting judges here agreed upon, is of great importance in that it suggested the method of determining the composition of the Council of the League of Nations, where the five great Powers, viz., the United States, the British Empire, France, Italy, and Japan, are continuously represented, while the Assembly from time to time at discretion, chooses the four other members of the League who shall be represented on the Council.

Inequality of contribution toward the expenses of the 
Secretariat is allowed by Article VI, 5 , which provides that such expenses shall be borne by the members of the League in accordance with the apportionment of the expenses of the International Bureau of the Universal Postal Union. ${ }^{1}$

For the purpose of admitting new members to the League, the principle of equality is recognized. New members may be admitted by a two-thirds vote of the Assembly, in which body all members are equally represented. The principle of equality is recognized in all cases where the decisions of the Assembly are made without reference to whether or not the members of the Assembly are represented on the Council. But in matters upon which the agreement of those

1 For the purpose of assessment the countries are divided into seven classes and each class is assessed a fixed number of units of expenses. For the seven classes, the number of units is fixed as follows: class 1, 25 units; class 2, 20 units; class 3, 15 units; class 4, 10 units; class 5, 5 units; class 6, 3 units; and class 7, 1 unit. When these coefficients are multiplied by the number of countries in each class, the products thus obtained, when added together, furnish the total number of units by which the total expense of the Union is divided to ascertain the assessment per unit of expense. Thus in 1903 the Postmaster of the United States reported that his department was assessed 26 units out of the total of 656 units, and that the amount paid by the United States was $\$ 958.44$. (United States Post Office Report, 1903.)

The following classification has been made:

Class 1: United States, Germany, Great Britain, France, Hungary, British India, Australia, Canada, British colonies and protectorates of South Africa, all other British colonies and protectorates, Italy, Japan, Russia, and Turkey.

Class 2: Spain.

Class 3: Belgium, Brazil, Egypt, the Netherlands, Roumania, Sweden, Switzerland, Algeria, the French colonies and protectorates of Indo-China, all other French colonies, all the insular possessions of the United States, and the Dutch Indies.

Class 4: Denmark, Norway, Portugal, Portuguese colonies of Africa, all other Portuguese colonies.

Class 5: Argentine, Bosnia-Herzegovina, Bulgaria, Chile, Colombia, Greece, Mexico, Peru, Serbia, and Tunis.

Class 6: Bolivia, Costa Rica, Cuba, Dominican Republic, Ecuador, Guatemala, Haiti, Honduras, Luxembourg, Nicaragua, Panama, Paraguay, Persia, Salvador, Siam, Uruguay, Venezuela, German protectorate in Africa, German protectorate in Asia and Australasia, Danish colonies, Dutch Antilles, and Dutch Guiana.

Class 7: Congo Free State, Korea, Crete, Spanish settlements (établissements) in the Gulf of Guinea, all Italian colonies, and Montenegro. (Article 38 of the Regulations for the execution of the Univeral Postal Convention signed at Rome, May 26, 1906. Hertslet's Commercial Treaties, XXV, pp. 492-493.) 


\section{THE NEW INTERNATIONAL LAW}

members represented on the Council is required, in addition to a majority of the other members of the League (excluding disputants), the principle of equality in the Assembly's decisions is sacrificed because all members of the League are not represented on the Council. The same is true with regard to amendments. They must be approved by a majority of the members of the League including those represented on the Council. In case all the members of the Assembly agreed to a report made according to Article $\mathrm{XV}$ or to an amendment, the principle of equality would be recognized, but the fact that the vote of a member of the Council must be in favor of the proposition before it is binding, and that it will be binding without the votes of all members of the Assembly, indicates that those members of the League having representatives on the Council are favored in these cases. Thus it is seen that the members of the League are not equal in representation (on the Council), or in the most important decisions, in voting power. This, however, is only a recognition of the actual political superiority of the greater Powers; it does not derogate from the principle of equality before the law.

The League an International Person of a New Type. It has been seen that the League of Nations is not a State in any sense of the term, nor is it a government through which the sovereignty of any particular State is expressed. It cannot properly be called an alliance or a confederation, although it is more like the latter than any known international organization. What, then, is its nature, and juridical status in international law?

It is an international person voluntarily created by the organized, sovereign States which form its membership, for certain definite objects and ends which are enumerated in the Covenant. It is, itself, a subject of international law, 
but at the same time it is the agency of the member States to firmly establish the understandings of international law among the Governments of those States. It does this by using methods of arbitration and conciliation in settling disputes, and by creating a Court of International Justice. One of the functions of this international person is to assume the trusteeship of the Saar Basin for a period of at least fifteen years; this means that it is vested with a legal title to, and with legal authority over, the territory of the Basin. In other words, all the rules of international law which apply in restraining one government from encroaching on the rights of another, apply to the League in its government of the Basin, except as otherwise stipulated by the Versailles Treaty. The officials of the League enjoy diplomatic privileges and immunities when engaged on League business; the representatives of the members of the League enjoy the same privileges and immunities. Inviolability attaches to the buildings and property occupied by the League or its officials or by representatives attending meetings of the League.

The League maintains no ambassadors or ministers at the capitals of its members. The purpose of such representatives is to furnish an agency through which one government deals with another. In case of the League this purpose is fulfilled, and the objects for which the organization was created are attained, through the three instrumentalities provided for in the Covenant. When the Assembly and the Council are not in session, the permanent Secretariat is the central agency for transacting League business falling within its sphere.

While possessing some attributes of sovereignty which have hitherto been regarded as attaching to sovereignty over any particular State, and as expressed by the Govern- 
ment of that State, the League possesses only those attributes which the members believed could better be assigned to a common agency than retained by themselves. They believed that by granting to this continuous international agency certain so-called rights of sovereignty formerly belonging to themselves, the residue of sovereignty retained by them would be more secure, and not liable to destruction by conquest of a foreign Power. They further saw that they would be represented in the League, the common agency for exercising those attributes of sovereignty voluntarily given it by the member States. In other words, a new international person has been created, and the members of the League have clothed that person with only enough power, machinery, and sovereignty, to make reasonable of expectation the attainment of the ends for which it is primarily created, viz., the maintenance of international peace and security, and the promotion of international coöperation, through the development of international law. 


\section{H A P T E R XI}

\section{CONCLUSIONS}

In forming conclusions as to the effect of the League of Nations upon international law in the future, it is well to recapitulate the defects in that law, and in the general international system, which existed before the establishment of the League, and then note the remedies or improvements brought about, or likely to be brought about, by the formation of the League.

The defects and weaknesses in the system existing up to the time of the adoption of the Covenant and subsequent establishment of the League of Nations, may be indicated by the following questions:

(1) Of conflicting conceptions of international law, which was the correct conception? Was there really a system of international law, or only a code of ethics to be regarded or disregarded at will? If there was a system of law, was it positive or natural law, and did the nations of the world need a system of positive law to govern them in their relations with one another?

(2) Granting that the need of a system of law was realized, were the methods of developing that law adequate for the changing conditions in international relationship?

(3) Was the need of a system of law felt so keenly by the nations of the world that they felt prepared to join together in giving effect to the law and providing sanctions to uphold it?

(4) Was the international machinery for administering 
the law and applying it to disputes between nations, adequate for the purpose?

(5) And finally, was the theory of international law formulated in the seventeenth century under the then prevailing notions of sovereignty, and economic separateness of nations, adequate in every respect for the world of 1920 ?

The answers to these questions have been given in the body of this paper. They may be summarized in a single paragraph.

In view of the preamble of the Covenant which makes the understandings of international law the actual rule of conduct among Governments, and of that section of the Versailles Treaty providing for the trial of certain Germans for violation of the laws and customs of war, it is seen that international law is not a code of ethics, but is a system of law. The Covenant shows plainly that the nations now realize the need of a system of positive law. They also realize the inadequacy of the old machinery for administering and applying the law, and have by the Covenant provided new agencies for these purposes, the most important of which is the court of international justice. They have felt the need of a system of law so keenly that they have united to give effect to the rule of law, and have agreed to provide sanctions in certain cases where the supremacy of the law is threatened. They have agreed to modify the hitherto prevailing conception as to what a sovereign nation may or may not do, and have cast their lot with a common league of all, to the end that the government of the world may be a government by law and not by diplomats closeted in their secret chambers. 



\section{APPENDICES}

\section{APPENDIX No. I}

\section{THE SMUTS PROPOSALS}

OwING to the fact that many of the proposals of the South African statesman, Jan Christian Smuts, were incorporated into the League of Nations Covenant, the condensed form of his plan is here given. In the original work entitled The League of Nations: A Practical Suggestion, ${ }^{1}$ General Smuts discusses in detail each of the twenty-one points of his plan, but the heart of each of his suggestions was summarized by him as follows:

1. That in the vast multiplicity of territorial, economic, and other problems with which the conference will find itself confronted it should look upon the setting up of a league of nations as its primary and basic task, and as supplying the necessary organ by means of which most of those problems can find their only stable solution. Indeed, the conference should regard itself as the first or preliminary meeting of the league, intended to work out its organization, functions, and programme.

2. That, so far at any rate as the peoples and territories formerly belonging to Russia, Austria-Hungary, and Turkey are concerned, the league of nations should be considered as the reversionary in the most general sense and as clothed with the right of ultimate disposal in accordance with certain fundamental principles. Reversion to the league of nations should be substituted for any policy of national annexation.

3. These principles are: firstly, that there shall be no annexation of any of these territories to any of the victorious Powers, and secondly, that in the future government of these territories and peoples the rule of self-determination, or the consent of the governed to their form of government, shall be fairly and reasonably applied.

4. That any authority, control, or administration which may be necessary in respect of these territories and peoples, other than their

Published December 16, 1918. 
own self-determined autonomy, shall be the exclusive function of and shall be vested in the league of nations and exercised by or on behalf of it.

5. That it shall be lawful for the league of nations to delegate its authority, control, or administration in respect of any people or territory to some other state whom it may appoint as its agent or mandatory, but that wherever possible the agent or mandatory so appointed shall be nominated or approved by the autonomous people or territory,

6. That the degree of authority, control, or administration exercised by the mandatory state shall in each case be laid down by the league in a special act or charter, which shall reserve to it complete power to ultimate control and supervision, as well as the right of appeal to it from the territory or people affected against any gross breach of the mandate by the mandatory state.

7. That the mandatory state shall in each case be bound to maintain the policy of the open door, or equal economic opportunity for all, and shall form no military forces beyond the standard laid down by the league for the purposes of internal police.

8. That no new state arising from the old empires be recognized or admitted into the league unless on condition that its military forces and armaments shall conform to the standard laid down by the league in respect of it from time to time.

9. That, as the successor to the empires, the league of nations will directly and without power of delegation watch over the relations inter se of the new independent states arising from the break-up of those empires, and will regard as a very special task the duty of conciliating and composing differences between them with a view to the maintenance of good order and general peace.

10. The constitution of the league will be that of a permanent conference between the Governments of the constituent states for the purpose of joint international action in certain defined respects, and will not derogate from the independence of those states. It will consist of a general conference, a council, and courts of arbitration and conciliation.

11. The general conference, in which all constituent states will have equal voting power, will meet periodically to discuss matters submitted to it by the council. These matters will be general measures of international law or arrangements or general proposals for limitation of armaments for securing world peace, or any other general resolutions, the discussion of which by the conference is desired by the council before they are forwarded for the approval of the constituent Governments. 
Any resolutions passed by the conference will have the effect of recommendations to the national Governments and Parliaments.

12. The council will be the executive committee of the league, and will consist of the Prime Ministers or Foreign Secretaries or other authoritative representatives of the Great Powers, together with the representatives drawn in rotation from two panels of the middle Powers and minor states respectively, in such a way that the Great Powers have a bare majority. A minority of three or more can veto any action or resolution of the council.

13. The council will meet periodically, and will, in addition, hold an annual meeting of Prime Ministers or Foreign Secretaries for a general interchange of views, and for a review of the general policies of the league. It will appoint a permanent secretariat and staff, and will appoint joint committees for the study and coördination of the international questions with which the council deals, or questions likely to lead to international disputes. It will also take the necessary steps for keeping up proper liaison, not only with the Foreign Offices of the constituent Governments, but also with the authorities acting on behalf of the league in various parts of the world.

14. Its functions will be:

(a) To take executive action or control in regard to the matters set forth in Section A [that is, points 1 to 9] or under any international arrangements or conventions;

(b) To administer and control any property of an international character, such as international waterways, rivers, straits, railways, fortifications, air stations, etc.;

(c) To formulate for the approval of the Governments general measures of international law, or arrangements for limitation of armaments or promotion of world peace.

(Its remaining functions in regard to world peace are dealt with in the following Section C [that is, points 14 to 21]).

15. That all the states represented at the peace conference shall agree to the abolition of conscription or compulsory military service; and that their future defence shall consist of militia or volunteers, whose numbers and training shall, after expert inquiry, be fixed by the council of the league.

16. That while the limitation of armaments in the general sense is impracticable, the council of the league shall determine what direct military equipment and armament is fair and reasonable in respect of the forces laid down under paragraph 15, and that the limits fixed by the council shall not be exceeded without its permission. 
17. That all factories for the manufacture of direct weapons of war shall be nationalized and their production shall be subject to the inspection of officers of the council; and that the council shall be furnished periodically with returns of imports and exports of munitions of war into or from territories of its members, and as far as possible into or from other countries.

18. That the peace treaty shall provide that the members of the league bind themselves jointly and severally not to go to war with one another -

(a) without previously submitting the matter in dispute to arbitration, or to inquiry by the council of the league; and

(b) until there has been an award, or a report by the council; and

(c) not even then, as against a member which complies with the award, or with the recommendation (if any) made by the council in its report.

19. That the peace treaty shall provide that if any member of the league breaks its covenant under paragraph 18, it shall ipso facto become at war with all the other members of the league, which shall subject it to complete economic and financial boycott, including the severance of all trade and financial relations and the prohibition of all intercourse between their subjects and the subjects of the covenant-breaking state, and the prevention, as far as possible, of the subjects of the covenantbreaking state from having any commercial or financial intercourse with the subjects of any other state, whether a member of the league or not.

While all members of the league are obliged to take the above measures, it is left to the council to recommend what effective naval or military force the members shall contribute, and, if advisable, to absolve the smaller members of the league from making such contribution.

The covenant-breaking state shall after the restoration of peace be subject to perpetual disarmament and to the peaceful régime established for new states under paragraph 8.

20. That the peace treaty shall further provide that if a dispute should arise between any members of the league as to the interpretation of a treaty, or as to any question of international law, or as to any fact which if established would constitute a breach of any international obligation, or as to any damage alleged and the nature and measure of the reparation to be made therefor, and if such dispute cannot be settled by negotiation, the members bind themselves to submit the dispute to arbitration and to carry out any award or decision which may be rendered.

21. That if on any ground it proves impracticable to refer such 


\section{APPENDIX}

dispute [that is non-justiciable disputes] to arbitration, either party to the dispute may apply to the council to take the matter of the dispute into consideration. The council shall give notice of the application to the other party, and make the necessary arrangements for the hearing of the dispute. The council shall ascertain the facts in regard to the dispute and make recommendations based on the merits, and calculated to secure a just and lasting settlement. Other members of the league shall place at the disposal of the council all information in their possession which bears on the dispute. The council shall do its utmost by mediation and conciliation to induce the disputants to agree on a peaceful settlement. The recommendations shall be addressed to the disputants and shall not have the force of decisions. If either party threatens to go to war in spite of the recommendations, the council shall publish its recommendations. If the council fails to arrive at recommendations, both the majority and the minority on the council may publish statements of the respective recommendations they favor, and such publication shall not be regarded as an unfriendly act by either of the disputants. 


\section{APPENDIX No. II}

A DRAFT OF THE COMPOSITE COVENANT MADE BY THE LEGAL ADVISERS OF THE COMMISSION ON THE LEAGUE

\section{PRESENTED BY MR. LODGE}

August 20, 1919 - Ordered to be printed

Senate Doc. 74, 66 Cong. 1st Session

\section{COVENANT}

\section{Preamble}

In order to secure international peace and security by the acceptance of obligations not to resort to the use of armed force, by the prescription of open, just, and honorable relations between nations, by the firm establishment of the understandings of international law as the actual rule of conduct among governments, and by the maintenance of justice and a scrupulous respect for all treaty obligations in the dealings of organized peoples with one another, and in order to promote international coöperation, the powers signatory to this covenant adopt this constitution of the league of nations.

\section{Article 1}

The action of the high contracting parties under the terms of this covenant shall be effected through the instrumentality of meetings of delegates representing the high contracting parties, of meetings at more frequent intervals of an executive council representing the States more immediately concerned in the matters under discussion, and of a permanent international secretariat to be established at the capital of the league.

\section{Article 2}

Meetings of the body of delegates shall be held from time to time as occasion may require for the purpose of dealing with matters within the sphere of action of the league.

Meetings of the body of delegates shall be held at the capital of the league or at such other place as may be found convenient and shall 
consist of not more than two representatives of each of the high contracting parties.

An ambassador or minister of one of the high contracting parties shall be competent to act as its representative.

All matters of procedure at meetings of the body of delegates, including the appointment of committees to investigate particular matters, shall be regulated by the body of delegates and may be decided by a majority of those present at the meeting.

\section{Article 3}

The representatives of the States members of the league directly affected by matters within the sphere of action of the league will meet as an executive council from time to time as occasion may require.

The United States of America, Great Britain, France, Italy, and Japan shall be deemed to be directly affected by all matters within the sphere of action of the league. Invitations will be sent to any power whose interests are directly affected, and no decision taken at any meeting will be binding on a State which was not invited to be represented at the meeting.

Such meetings will be held at whatever place may be decided on, or failing any such decision at the capital of the league, and any matter affecting the interests of the league or relating to matters within its sphere of action or likely to affect the peace of the world may be dealt with.

\section{Article 4}

The permanent secretariat of the league shall be established at - which shall constitute the capital of the league. The secretariat shall comprise such secretaries and staff as may be required, under the general direction and control of a chancellor of the league by whom they shall be appointed.

The chancellor shall act as secretary at all meetings of the body of delegates or of the executive council.

The expenses of the secretariat shall be borne by the States members of the league in accordance with the distribution among members of the Postal Union of the expenses of the International Postal Union.

\section{Article 5}

Representatives of the high contracting parties and officials of the league when engaged on the business of the league shall enjoy diplomatic privileges and immunities, and the buildings occupied by the 
league or its officials or by representatives attending its meetings shall enjoy the benefits of extraterritoriality.

\section{Article 6}

Admission to the league of States who are not signatories of this covenant requires the assent of not less than two-thirds of the body of delegates.

No State shall be admitted to the league except on condition that its military and naval forces and armaments shall conform to standards prescribed by the league in respect of it from time to time.

\section{Article 7}

The high contracting parties undertake to respect and preserve as against external aggression the territorial integrity and existing political independence of all States members of the league.

\section{Article 8}

The high contracting parties recognize the principle that the maintenance of peace will require the reduction of national armaments to the lowest point consistent with domestic safety and the enforcement by common action of international obligations; and the executive council shall formulate plans for effecting such reduction. It shall also inquire into the feasibility of abolishing compulsory military service and the substitution therefor of forces enrolled upon a voluntary basis and into the military and naval equipment which it is reasonable to maintain.

The high contracting parties further agree that there shall be full and frank publicity as to all national armaments and military or naval programs.

\section{Article 9}

Any war or threat of war, whether immediately affecting any of the high contracting parties or not, is hereby declared a matter of concern to the league and the high contracting parties reserve the right to take any action that may be deemed wise and effectual to safeguard the peace of nations.

It is hereby also declared and agreed to be the friendly right of each of the high contracting parties to draw the attention of the body of delegates or of the executive council to any circumstances anywhere which threaten to disturb international peace or the good understanding between nations upon which peace depends. 


\section{Article 10}

The high contracting parties agree that should disputes arise between them which can not be adjusted by the ordinary processes of diplomacy, they will in no case resort to armed force without previously submitting the questions and matters involved either to arbitration or to inquiry by the executive council, and until three months after the award by the arbitrators or a recommendation by the executive council; and that they will not even then resort to ármed force as against a member of the league which complies with the award of the arbitrators or the recommendation of the executive council.

\section{Article 11}

The high contracting parties agree that whenever any dispute or difficulty shall arise between them which they recognize to be suitable for submission to arbitration and which can not be satisfactorily settled by diplomacy, they will submit the whole subject matter to arbitration and will carry out in full good faith any award or decision that may be rendered.

\section{Article 12}

The executive council will formulate plans for the establishment of a permanent court of international justice and this court will be competent to hear and determine any matter which the parties recognize as suitable for submission to it for arbitration under the foregoing article.

\section{Article 13}

If there should arise between States members of the league any dispute likely to lead to a rupture, which is not submitted to arbitration as above, the high contracting parties agree that they will refer the matter to the executive council; either party to the dispute may give notice to the chancellor of the existence of the dispute, and the chancellor will make all necessary arrangements for a full investigation and consideration thereof. For this purpose the parties agree to communicate to the chancellor statements of their case, with all the relevant facts and papers.

Where the efforts of the council lead to the settlement of the dispute a statement shall be prepared for publication indicating the nature of the dispute and the terms of settlement, together with such explanations as may be appropriate. If the dispute has not been settled a report by the council shall be published, setting forth with all 
necessary facts and explanations, the recommendations which the council think just and proper for the settlement of the dispute. If the report is unanimously agreed to by the members of the council, other than the parties to the dispute, the high contracting parties agree that none of them will go to war with any party which complies with its recommendations. If no such unanimous report can be made it shall be the duty of the majority to issue a statement indicating what they believe to be the facts and containing the recommendations which they consider to be just and proper.

The executive council may in any case under this article refer the dispute to the body of delegates. The dispute shall be so referred at the request of either party to the dispute. In any case referred to the body of delegates all the provisions of this article relating to the action and powers of the executive council shall apply to the action and powers of the body of delegates.

\section{Ar'ticle 14}

Should any of the high contracting parties be found by the league to have broken or disregarded its covenants under Article $\mathrm{X}$ it shall thereby ipso facto be deemed to have committed an act of war against all the other members of the league, which shall immediately subject it to the severance of all trade or financial relations, the probibition of all intercourse between their nationals and the nationals of the covenantbreaking State, and the prevention, so far as possible, of all financial, commercial, or personal intercourse between the nationals of the covenant-breaking State and the nationals of any other State, whether a member of the league or not.

It shall be the duty of the executive council in such a case to recommend what effective military or naval force the members of the league shall severally contribute to the armed forces to be used to protect the covenants of the league.

The high contracting parties agree, further, that they will mutually support one another in the financial and economic measures which are taken under this article in order to minimize the loss and inconvenience resulting from the above measures, and that they will mutually support one another in resisting any special measures aimed at one of their number by the covenant-breaking State, and that they will afford passage through their territory to the forces of any of the high contracting parties who are coöperating to protect the covenants of the league. 


\section{Article 15}

In the event of disputes between one State member of the league and another State which is not a member of the league, or between States not members of the league, the high contracting parties agree that the State or States not members of the league shall be invited to become ad hoc members of the league, and upon acceptance of any such invitation, the above provisions shall be applied with such modifications as may be deemed necessary by the league.

Upon such invitation being given the executive council shall immediately institute an inquiry into the circumstances and merits of the dispute and recommend such action as may seem best and most effectual in the circumstances.

In the event of a power so invited refusing to become ad hoc a member of the league, and taking any action against a State member of the league, which in the case of a State member of the league would constitute a breach of Article X, the provisions of Article XIV shall be applicable as against the State taking such action.

If both parties to the dispute when so invited refuse to become ad hoc members of the league the executive council may take such action and make such recommendations as will prevent hostilities and will result in the settlement of the dispute.

\section{Article 16}

The high contracting parties entrust to the league the general supervision of the trade in arms and ammunition with the countries in which the control of this traffic is necessary in the common interest.

\section{Article 17}

The high contracting parties agree that in respect of territories which formerly belonged to the German Empire or to Turkey and which are inhabited by peoples unable at present to secure for themselves the benefits of a stable administration, the well being of these peoples constitutes a sacred trust for civilization and imposes upon the States members of the league the obligation to render help and guidance in the development of the administration. They recognize that all policies of administration or economic development should be based primarily upon the well-considered interests of the peoples themselves, upon the maintenance of the policy of the open door and of equal opportunity for all the high contracting parties in respect of the use and development of the economic resources of the territory. No military or naval forces shall be formed among the inhabitants 
of the territories in excess of those required for purposes of defense and of internal police.

\section{Article 18}

The high contracting parties will work to establish and maintain fair hours and humane conditions of labor for all those within their several jurisdictions and they will exert their influence in favor of the adoption and maintenance of a similar policy and like safeguards wherever their industrial and commercial relations extend. Also they will appoint commissions to study conditions of industry and labor in their international aspects and to make recommendations thereon, including the extension and improvement of existing conventions.

\section{Article 19}

The high contracting parties agree that they will make no law prohibiting or interfering with the free exercise of religion, and that they will in no way discriminate, either in law or in fact, against those who practice any particular creed, religion, or belief whose practices are not inconsistent with public order or public morals.

\section{Article 20}

The high contracting parties will agree upon provisions intended to secure and maintain freedom of transit and just treatment for the commerce of all States members of the league.

\section{Article 21}

The high contracting parties agree that any treaty or international engagement entered into between States members of the league shall be forthwith registered with the chancellor and as soon as possible published by him.

\section{Article 22}

The high contracting parties severally agree that the present covenant is accepted as abrogating all obligations inter se which are inconsistent with the terms hereof, and solemnly engage that they will not hereafter enter into any engagements inconsistent with the terms hereof.

In case any of the powers signatory hereto or subsequently admitted to the league shall, before becoming a party to this covenant, have undertaken any obligations which are inconsistent with the terms of this covenant, it shall be the duty of such power to take immediate steps to procure its release from such obligations. 


\section{APPENDIX No. III}

\section{LEAGUE OF NATIONS}

\section{COMPARISON OF THE PLAN FOR THE LEAGUE OF NATIONS}

SHOWING the ORIGINAl DRAFT AS PRESENTEd TO THE COMMISSION CONSTITUTED BY THE PRELIMINARY PEACE CONFERENCE IN SESSION AT VERSAILles, FRANCE, TOGETHER

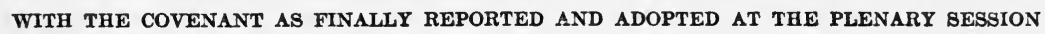
OF THE PEACE CONFERENCE.

\section{PRESENTED BY MR. PITTMAN \\ MAY 20, 1919 - Ordered to be printed \\ Senate Doc. 7, 66 Cong. 1st Session}

Covenant for the League of Nations Showing the Preliminary Reported Draft and the Covenant as Finally Adopted at the Plenary Session.

In the revised text, the italics which are the author's show changes from the original, or new matter. The revised text has been corrected from the offlcial text of the Versailles Treaty.

\section{PRELIMINARY DRAFT}

\section{DRAFT FINALLY ADOPTED}

\section{Covenant - Preanble}

In order to promote international coöperation and to secure international peace and security by the acceptance of obligations not to resort to war, by the prescription of open, just, and honorable relations between nations, by the firm establishment of the understandings of international law as the actual rule of conduct among Governments, and by the maintenance of justice and a scrupulous respect for all treaty obligations in the dealings of or-
The high contracting parties, in order to promote international coöperation, to achieve international peace and security by the acceptance of obligations not to resort to war, by the prescription of open, just, and honorable relations between nations, by the firm establishment of the understandings of international laws as the actual rule of conduct among governments and by the maintenance of justice and a scrupulous respect for all treaty obligations 
ganized people with one another, the powers signatory to this covenant adopt this constitution of the league of nations.

See Par. 1, Article 7.

See Par. 2, Article 7. in the dealings of organized peoples with one another, agree to this covenant of the league of nations.

\section{Article 1}

The original members of the league of nations shall be those of the signatories which are named in the annex to this covenant and also such of those other States named in the annex as shall accede without reservation to this covenant. Such accession shall be effected by a declaration deposited with the secretariat within two months of the coming into force of the covenant. Notice thereof shall be sent to all other members of the league.

Any fully self-governing State, dominion, or colony not named in the annex may become a member of the league if its admission is agreed by two-thirds of the assembly, provided that it shall give effective guaranties of its sincere intention to observe its international obligations and shall accept such regulations as may be prescribed by the league in regard to its military, naval and air forces and armaments.

Any member of the league may, after two years' notice of its intention so to do, withdraw from the league, provided that all its international obligations and all its obligations under this covenant shall have been fulfilled at the time of its withdrawal. 
Article 1

The action of the high contracting parties under the terms of this covenant shall be effected through the instrumentality of meeting of a body of delegates representing the high contracting parties, of meeting at more frequent intervals of an executive council, and of a permanent international secretariat to be established at the seat of the league.

\section{Article 2}

Meetings of the body of delegates shall be held at stated intervals and from time to time as occasion may require for the purpose of dealing with matters within the sphere of action of the league.

Meetings of the body of delegates shall be held at the seat of the league or at such other place as may be found convenient, and shall consist of representatives of the high contracting parties.

Each of the high contracting parties shall have one vote, but may not have more than three representatives.

Article 3

The executive council shall consist of representatives of the United States of America, the British Empire, France Italy,

\section{Article 2}

The action of the league under this covenant shall be effected through the instrumentality of an assembly and of a council, with a permanent secretariat.

\section{Article 3}

The assembly shall consist of representatives of the members of the league.

The assembly shall meet at stated intervals and from time to time as occasion may require, at the seat of the league or at such other place as may be decided upon.

The assembly may deal at its meetings with any matter within the sphere of action of the league or affecting the peace of the world.

At meetings of the assembly each member of the league shall have one vote, and may have not more than three representatives.

\section{Article 4}

The council shall consist of representatives of the United States of America, of the British Empire, of France, of Italy, and 
and Japan, together with representatives of four other States, members of the league. The selection of these four States shall be made by the body of delegates on such principles and in such manner as they think fit. Pending the appointment of these representatives of the other States, representatives of - shall be members of the executive council.

Meetings of the council shall be held from time to time as occasion may require, and at least once a year, at whatever place may be decided upon, or, failing any such decision, at the seat of the league, and any matter within the sphere of action of the league or affecting the peace of the world may be dealt with at such meetings.

Invitations shall be sent to any power to attend a meeting of the council at which matters directly affecting its interests are to be discussed, and no decision taken at any meeting will be binding on such powers unless so invited. of Japan, together with represent. atives of four other members of the league. These four members of the league shall be selected by the assembly from time to time in its discretion. Until the appointment of the representatives of the four members of the league first selected by the assembly, representatives of Belgium, Brazil, Spain, and Greece shall be members of the council.

With the approval of the majority of the assembly, the council may name additional members of the league, whose representatives shall always be members of the council; the council with like approval may increase the number of members of the league to be selected by the assembly for representation on the council.

The council shall meet from time to time as occasion may require, and at least once a year, at the seat of the league, or at such other place as may be decided upon.

The council may deal at its meetings with any matter within the sphere of action of the league or affecting the peace of the world.

Any member of the league not represented on the council shall be invited to send a representative to sit as a member at any meeting of the council during the consideration of matters specially affecting the interests of that member of the league. 
At meetings of the council each member of the league represented on the council shall have one vote, and may have not more than one representative.

Article 4

All matter of procedure at meetings of the body of delegates or the executive council, including the appointment of the committees to investigate particular matters, shall be regulated by the body of delegates or the executive council, and may be decided by a majority of the States represented at the meeting.

The first meeting of the body of delegates and of the executive council shall be summoned by the President of the United States of America.

\section{Article 5}

The permanent secretariat of the league shall be established at seat of the league. The secretariat shall comprise such secretaries and staff as may be required, under the general direction and control of a secretary

\section{Article 5}

Except where otherwise expressly provided in this covenant, or by the terms of this treaty, decisions at any meeting of the assembly or of the council shall require the agreement of all the members of the league represented at the meeting.

All matters of procedure at meetings of the assembly or of the council, including the appointment of committees to investigate particular matters, shall be regulated by the assembly or by the council, and may be decided by a majority of the members of the league represented at the meeting.

The first meeting of the assembly and the first meeting of the council shall be summoned by the President of the United States of America.

\section{Article 6}

The permanent secretariat shall be established at the seat of the league. The secretariat shall comprise a secretariat general and such secretaries and staff as may be required.

The first secretary general shall be the person named in the annex; 
general of the league, who shall be chosen by the executive council;

the secretariat shall be appointed by the secretary general, subject to confirmation by the executive council.

The secretary general shall act in that capacity at all meetings of the body of delegates or of the executive council.

The expenses of the secretariat shall be borne by the States members of the league in accordance with apportionment of the expenses of the International Bureau of the Universal Postal Union.

Article 6

See Par. \&, Article \&.

Representatives of the high contracting parties and officials of the league when engaged on the business of the league shall enjoy diplomatic privileges and immunities, and the buildings occupied by the league or its officials or by representatives attending its meetings shall enjoy the benefits of extraterritoriality. thereafter the secretary general shall be appointed by the council with the approval of the majority of the assembly.

The secretaries and the staff of the secretariat shall be appointed by the secretary general with the approval of the council.

The secretary general shall act in that capacity at all meetings of the assembly and of the council.

The expenses of the secretariat shall be borne by the members of the league in accordance with the apportionment of the expenses of the International Bureau of the Universal Postal Union.

\section{Article 7}

The seat of the league is established at Geneva.

The council may at any time decide that the seat of the league shall be established elsewhere.

All positions under or in connection with the league, including the secretariat, shall be open equally to men and women.

Representatives of the members of the league and officials of the league when engaged on the business of the league shall enjoy diplomatic privileges and immunities.

The buildings and other property occupied by the league or its officials or by representatives attending its meetings shall be inviolable. 


\section{APPENDIX}

\section{Article 7}

Admission to the league of States not signatories to the covenant and not named in the protocol hereto as States to be invited to adhere to the covenant requires the assent of the not less than two-thirds of the States represented in the body of delegates, and shall be limited to fully selfgoverning countries, including dominions and colonies.

No State shall be admitted to the league unless it is able to give effective guaranties of its sincere intention to observe its international obligations, and unless it shall conform to such principles as may be prescribed by the league in regard to its naval and military forces and armaments.

\section{Article 8}

The high contracting parties recognize the principle that the maintenance of peace will require the reduction of national armaments to the lowest point consistent with national safety and the enforcement by common action of international obligations, having special regard to the geographical situation and circumstances of each State; and the executive council shall formulate plans for effecting such reduction.

\section{ARticle 8}

See Par. 2, Article 1.

The members of the league recognize that the maintenance of a peace requires the reduction of national armaments to the lowest point consistent with national safety and the enforcement by common action of international obligations.

The council, taking account of the geographical situation and circumstances of each State, shall formulate plans for such reduction for the consideration and action of the several Governments.

Such plans shall be subject to reconsideration and revision at least every 10 years. 
The executive council shall also determine for the consideration and action of the several governments what military equipment and armament is fair and reasonable in proportion to the scale of forces laid down in the program of disarmament, and these limits, when adopted, shall not be exceeded without the permission of the executive council.

The high contracting parties agree that the manufacture by private enterprise of munitions and implements of war lends itself to grave objections, and direct the executive council to advise how the evil effects attendant upon such manufacture can be prevented, due regard being had to the necessities of these countries which are not able to manufacture for themselves the munitions and implements of war necessary for their safety.

The high contracting parties undertake in no way to conceal from each other the condition of such of their industries as are capable of being adapted to warlike purposes or the scale of their armaments, and agree that there shall be full and frank interchange of information as to their military and naval programs.

\section{Article 9}

A permanent commission shall be constituted to advise the league on the execution of the provisions
After these plans shall have been adopted by the several Governments, limits of armaments therein fixed shall not be exceeded without the concurrence of the council.

The members of the league agree that the manufacture by private enterprise of munitions and implements of war is open to grave objections. The council shall advise how the evil effects attendant upon such manufacture can be prevented, due regard being had to the necessities of those members of the league which are not able to manufacture the munitions and implements of war necessary for their safety.

The members of the league undertake to interchange full and frank information as to the scale of their armaments, their military and naval programs, and the condition of such of their industries as are adaptable to warlike purposes.

\section{Article 9}

A permanent commission shall be constituted to advise the council on the execution of the provi- 
of Article 8 and on military, naval and air questions generally.

\section{Article 10}

The high contracting parties undertake to respect and preserve as against external aggression the territorial integrity and existing political independence of all States members of the league. In case of any such aggression, or in case of any threat or danger of such aggression, the executive council shall advise upon the means by which the obligation shall be fulfilled.

\section{Article 11}

Any war or threat of war, whether immediately affecting any of the high contracting parties or not, is hereby declared a matter of concern to the league, and the high contracting parties reserve the right to take any action that may be deemed wise and effectual to safeguard the peace of nations.

It is hereby also declared and agreed to be the friendly right of each of the high contracting parties to draw the attention of the body of delegates or of the executive council to any circumstances affecting international intercourse sions of Articles 1 and 8 and on military and naval questions generally.

\section{Article 10}

The members of the league undertake to respect and preserve as against external aggression the territorial integrity and existing political independence of all members of the league. In case of any such aggression, or in case of any threat or danger of such aggression, the council shall advise upon the means by which this obligation shall be fulfilled.

\section{Article 11}

Any war or threat of was, whether immediately affecting any of the members of the league or not, is hereby declared a matter of concern to the whole league, and the league shall take any action that may be deemed wise and effectual to safeguard the peace of nations. In case any such emergency should arise, the secretary general shall, on the request of any member of the league, forthwith summon a meeting of the council.

It is also declared to be the friendly right of each member of the league to bring to the attention of the assembly or of the council any circumstance whatever affecting international relations which threatens to dis- 
which threaten to disturb international peace or the good understanding between nations upon which peace depends.

\section{Article 12}

The high contracting parties agree that should disputes arise between them which can not be adjusted by the ordinary processes of diplomacy they will in no case resort to war without previously submitting the question and matters involved either to arbitration or to inquiry by the executive council and until three months after the award by the arbitrators or a recommendation by the executive council; and that they will not even then resort to war as against a member of the league which complies with the award of the arbitrators or the recommendation of the executive council.

In any case under this article, the award of the arbitrators shall be made within a reasonable time, and the recommendation of the executive council shall be made within six months after the submission of the dispute.

\section{Article 13}

The high contracting parties agree that whenever any dispute or difficulty shall arise between them which they recognize to be suitable for submission to arbitration and which can not be satis- turb international peace or the good understanding between nations upon which peace depends.

\section{Article 12}

The members of the league agree that if there should arise between them any dispute likely to lead to a rupture, they will submit the matter either to arbitration or to inquiry by the council, and they agree in no case to resort to war until three months after the award by the arbitrators or the report by the council.

In any case under this article the award of the arbitrators shall be made within a reasonable time, and the report of the council shall be made within six months after the submission of the dispute.

\section{Article 13}

The members of the league agree that whenever any dispute shall arise between them which they recognize to be suitable for submission to arbitration and which can not be satisfactorily 
factorily settled by diplomacy, they will submit the whole matter to arbitration.

For this purpose the court of arbitration to which the case is referred shall be the court agreed upon by the parties or stipulated in any convention existing between them.

The high contracting parties agree that they will carry out in full good faith any award that may be rendered.

See Par. 1, Art. 12.

In the event of any failure to carry out the award, the executive council shall propose what steps can best be taken to give effect thereto.

\section{Article 14}

The executive council shall formulate plans for the establishment of a permanent court of international justice, and this court shall, when established, be settled by diplomacy, they will submit the whole subject matter to arbitration. Disputes as to the interpretation of a treaty, as to any question of international law, as to the existence of any fact which if established would constitute a breach of any international obligation, or as to the extent and nature of the reparation to be made for any such breach, are declared to be among those which are generally suitable for submission to arbitration.

For the consideration of any such dispute the court of arbitration to which the case is referred shall be the court agreed on by the parties to the dispute or stipulated in any convention existing between them.

The members of the league agree that they will carry out in full good faith any award that may be rendered and that they will not resort to war against a member of the league which complies therewith.

In the event of any failure to carry out such an award, the council shall propose what steps should be taken to give effect thereto.

\section{Article 14}

The council shall formulate and submit to the members of the league for adoption plans for the establishment of a permanent court of international justice. 
competent to hear and determine any matter which the parties recognize as suitable for submission to it for arbitration under the foregoing article.
The court shall be competent to hear and determine any dispute of an international character which the parties thereto submit to it. The court may also give an advisory opinion upon any dispute or question referred to it by the council or by the assembly.

\section{Article 15}

If there should arise between States, members of the league, any dispute likely to lead to rupture, which is not submitted to arbitration as above, the high contracting parties agree that they will refer the matter to the executive council; either party to the dispute may give notice of the existence of the dispute to the secretary general, who will make all necessary arrangements for a full investigation and consideration thereof. For this purpose the parties agree to communicate to the secretary general, as promptly as possible, statements of their case with all the relevant facts and papers, and the executive council may forthwith direct the publication thereof.

Where the efforts of the council lead to the settlement of the dispute, a statement shall be published indicating the nature of the dispute and the terms of settlement, together with such explanations as may be appropriate.

If the dispute has not been set-

\section{Article 15}

If there should arise between members of the league any dispute likely to lead to a rupture, which is not submitted to arbitration in accordance with Article 13, the members of the league agree that they will submit the matter to the council. Any party to the dispute may effect such submission by giving notice of the existence of the dispute to the secretary general, who will make all necessary arrangements for a full investigation and consideration thereof.

For this purpose the parties to the dispute will communicate to the secretary general, as promptly as possible, statements of their case, all the relevant facts and papers, and the council may forthwith direct the publication thereof.

The council shall endeavor to effect a settlement of any dispute, and if such efforts are successful a statement shall be made public giving such facts and explanations regarding the dispute, terms of settlement thereof as the council may deem appropriate.

If the dispute is not thus set- 
tled, a report by the council shall be published, setting forth with all necessary facts and explanations the recommendation which the council thinks just and proper for the settlement of the dispute.

If the report is unanimously agreed to by the members of the council other than the parties to the dispute, the high contracting parties agree that they will not go to war with any party which complies with the recommendations, and that if any party shall refuse so to comply the council shall propose measures necessary to give effect to the reason. If no such unanimous report can be made, it shall be the duty of the majority and the privilege of the minority to issue statements indicating what they believe to be the facts and containing the reasons which they consider to be just and proper. tled, the council either unanimously or by a majority vote shall make and publish a report containing a statement of the facts of the dispute and the recommendations which are deemed just and proper in regard thereto.

Any member of the league represented on the council may make public a statement of the facts of the dispute and of its conclusions regarding the same.

If a report by the council is unanimously agreed to by the members thereof other than the representatives of one or more of the parties to the dispute, the members of the league agree that they will not go to war with any party to the dispute which complies with the recommendations of the report.

If the council fails to reach a report which is unanimously agreed to by the members thereof, other than the representatives of one or more of the parties to the dispute, the members of the league reserve to themselves the right to take such action as they shall consider necessary for the maintenance of right and justice.

If the dispute between the parties is claimed by one of them, and is found by the council, to arise out of a matter which by international law is solely within the domestic jurisdiction of that party, the council shall so report and shall make no recommendation as to its settlement. 
The executive council may in any case under this article refer the dispute to the body of delegates. The dispute shall be so referred at the request of either party to the dispute, provided that such request must be made within 14 days after the submission of the dispute.

In any case referred to the body of delegates all the provisions of this article and of Article 12 relating to the action of the executive council shall apply to the action and powers of the body of delegates.
The council may in any case under this article refer the dispute to the assembly. The dispute shall be so referred at the request of either party to the dispute, provided that such request be made within 14 days after the submission of the dispute to the council.

In any case referred to the assembly all the provisions of this article and of Article 12, relating to the action and powers of the council, shall apply to the action and powers of the assembly, provided that a report made by the assembly, if concurred in by the representatives of those members of the league represented on the council and of a majority of the other members of the league, exclusive in each case of the representatives of the parties to the dispute, shall have the same force as a report by the council concurred in by all the members thereof other than the representatives of one or more of the parties to the dispute.

Article 16

Should any of the high contracting parties break or disregard its covenants under Article 12 it shall thereby ipso facto be deemed to have committed an act of war against all the other members of the league, which hereby undertake immediately to subject it to the severance of all trade or

\section{Article 16}

Should any member of the league resort to war in disregard of its covenants under Articles 12, 13 , or 15 , it shall ipso facto be deemed to have committed an act of war against all other members of the league, which hereby undertake immediately to subject it to the severance of all trade or 
financial relations, the prohibition of all intercourse between their nationals and the nationals of the covenant-breaking State, and the prevention of all financial, commercial, or personal intercourse between the nationals of the covenant-breaking State and the nationals of any other State, whether a member of the league or not.

It shall be the duty of the executive council in such cases to recommend what effective military or naval forces the members of the league shall severally contribute to the armed forces to be used to protect the covenants of the league.

The high contracting parties agree further that they will mutually support one another in the financial and economic measures which may be taken under this article, in order to minimize the loss and inconvenience resulting from the above measures, and that they will mutually support one another in resisting any special measures aimed at one of their number by the covenantbreaking State, and that they will afford passage through their territory to the forces of any of the high contracting parties who are coöperating to protect the covenants of the league. financial relations, the prohibition of all intercourse between their nationals and the nationals of the covenant-breaking State, and the prevention of all financial, commercial, or personal intercourse between the nationals of the covenant-breaking State and the nationals of any other State, whether a member of the league or not.

It shall be the duty of the council in such case to recommend to the several Governments concerned what effective military, naval or air forces the members of the league shall severally contribute to the armed forces to be used to protect the covenants of the league.

The members of the league agree, further, that they will mutually support one another in the financial and economic measures which are taken under this article, in order to minimize the loss and inconvenience resulting from the above measures, and that they will mutually support one another in resisting any special measures aimed at one of their number by the covenant-breaking State, and that they will take the necessary steps to afford passage through their territory to the forces of any of the members of the league which are coöperating to protect the covenants of the league.

Any member of the league which has violated any covenant 
of the league may be declared to be no longer a member of the league by a vote of the council concurred in by the representatives of all the other members of the league represented thereon.

\section{Article 17}

In the event of disputes between one State member of the league and another State which is not a member of the league, or between States not members of the league, the high contracting parties agree that the State or States not members of the league shall be invited to accept the obligations of membership in the league for the purposes of such dispute, upon such conditions as the executive council may deem just, and upon acceptance of any such invitation the above provisions shall be applied with such modifications as may be deemed necessary by the league.

Upon such invitation being given the executive council shall immediately institute an inquiry into the circumstances and merits of the dispute and recommend such action as may seem best and most effectual in the circumstances,

In the event of a power so invited refusing to accept the obligations of membership in the league for the purposes of such dispute, and taking any action against a State member of the

\section{Article 17}

In the event of a dispute between a member of the league and a State which is not a member of the league, or between States not members of the league, the State or States not members of the league shall be invited to accept the obligations of membership in the league for the purposes of such dispute, upon such conditions as the council may deem just. If such invitation is accepted, the provisions of Articles 12 to 16 , inclusive, shall be applied with such modifications as may be deemed necessary by the council.

Upon such invitation being given, the council shall immediately institute an inquiry into the circumstances of the dispute and recommend such action as may seem best and most effectual in the circumstances.

If a State so invited shall refuse to accept the obligations of membership in the league for the purposes of such dispute, and shall resort to war against a member of the league, the provisions 
league which in the case of a of Article 16 shall be applicable State member of the league would as against the State taking such constitute a breach of article 12, action.

the provisions of article 16 shall be applicable as against the State taking such action.

If both parties to the dispute, when so invited, refuse to accept the obligations of membership in the league for the purposes of such dispute, the executive council may take such action and make such recommendations as will prevent hostilities and will result in the settlement of the dispute.

\section{Article 18}

The high contracting parties agree that the league shall be intrusted with general supervision of the trade in arms and ammunitions with the countries in which the control of this traffic is necessary and in the common interest.

See Article 23.

If both parties to the dispute, when so invited refuse to accept the ob igations of membership in the league for the purposes of such dispute, the council may take such measures and make such recommendations as will prevent hostilities and will result in the settlement of the dispute.

See Par. 5, Article 23.

\section{Article 18}

Every convention or international engagement entered into henceforward by any member of the league shall be forthwith registered with the secretariat and shall as soon as possible be published by it. No such treaty or intentional engagement shall be binding until so registered.

\section{Article 19}

The assembly may from time to time advise the reconsideration by members of the league of treaties 
See Article 24.

See Article 25.

Article 19.

To those colonies and territories which as a consequence of the war have ceased to be under which have become inapplicable, and the consideration of international conditions whose continuance might endanger the peace of the world.

\section{Article 20}

The members of the league severally agree that this covenant is accepted as abrogating all obligations or understandings inter se which are inconsistent with the terms thereof, and solemnly undertake that they will not hereafter enter into any engagements inconsistent with the terms thereof.

In case members of the league shall, before becoming a member of the league, have undertaken any obligations inconsistent with the terms of this covenant, it shall be the duty of such member to take immediate steps to procure its release from such obligations.

\section{Article 21}

Nothing in this covenant shall be deemed to affect the validity of international engagements, such as treaties of arbitration or regional understandings like the Monroe Doctrine, for securing the maintenance of peace.

\section{Article 22}

To those colonies and territories which as a consequence of the late war have ceased to be 
the sovereignty of the States which formerly governed them, and which are inhabited by peoples not yet able to stand by themselves under the strenuous conditions of the modern world, there should be applied the principle that the well-being and development of such peoples form a sacred trust of civilization and that securities for the performance of this trust should be embodied in the constitution of the league.

The best method of giving practical effort of this principle is that the tutelage of such people should be intrusted to advanced nations who, by reason of their resources, their experience, or their geographical position, can best undertake this responsibility, and that this tutelage should be exercised by them as mandataries on behalf of the league.

The character of the mandate must differ according to the stage of the development of the people, the geographical situation of the territory, its economic conditions, and other similar circumstances.

Certain communities formerly belonging to the Turkish Empire have reached a stage of development where their existence as independent nations can be provisionally recognized, subject to the rendering - of administrative advice and assistance by a mandatary power until such time as they are able to stand alone. The under the sovereignty of the States which formerly governed them and which are inhabited by peoples not yet able to stand by themselves under the strenuous conditions of the modern world there should be applied the principle that the well-being and development of such peoples form a sacred trust of civilization and that securities for the performance of this trust should be embodied in this covenant.

The best method of giving practical effect to this principle is that the tutelage of such peoples be intrusted to advanced nations who by reasons of their resources, their experience, or their geographical position, can best undertake this responsibility, and who are willing to accept it, and that this tutelage should be exercised by them as mandataries on behalf of the league.

The character of the mandate must differ according to the stage of the development of the people, the geographical situation of the territory, its economic condition, and other similar circumstances.

Certain communities formerly belonging to the Turkish Empire have reached a stage of development where their existence as independent nations can be provisionally recognized, subject to the rendering of administrative advice and assistance by a mandatary until such time as they are able to stand alone. The wishes 
wishes to these communities must be a principal consideration in the selection of the mandatary power.

Other peoples, especially those of Central Africa, are at such a stage that the mandatary must be responsible for the administration of the territory, subject to conditions which will guarantee freedom of conscience or religion, subject only to the maintenance of public order and morals, the prohibition of abuses, such as the slave trade, the arms traffic, and the liquor traffic, and the prevention of the establishment of fortifications or military and naval bases, and of military training of the natives for other than police purposes and the defense of territory, and will also secure equal opportunities for the trade and commerce of other members of the league.

There are territories, such as Southwest Africa and certain of the South Pacific isles, which, owing to the sparseness of their population, or their small size, or their remoteness from the centers of civilization, or their geographical continuity to the mandatary State, and other circumstances, can be best administered under the laws of the mandatary State as integral portions thereof, subject to the safeguards above mentioned in the interests of indigenous population.

In every case of mandate the mandatary State shall render to of these communities must be a principal consideration in the selection of the mandatary.

Other peoples, especially those of central Africa, are at such a stage that the mandatary must be responsible for the administration of the territory under conditions which will guarantee freedom of conscience or religion, subject only to the maintenance of public order and morals, the prohibition of abuses, such as the slave trade, the arms traffic, and the liquor traffic, and the prevention of the establishment of fortifications or military and naval bases and of military training of the natives for other than police purposes and the defense of territory, and will also secure equal opportunities for the trade and commerce of other members of the league.

There are territories, such as southwest Africa and certain of the South Pacific islands, which, owing to the sparseness of their population or their small size or their remoteness from the centers of civilization or their geographical contiguity to the territory of the mandatary and other circumstances, can be best administered under the laws of the mandatary as integral portions of its territory, subject to the safeguards above mentioned in the interests of the indigenous populations. In every case of mandate the mandatary shall render to the 
the league an annual report in reference to the territory committed to its charge.

The degree of authority, control, or administration to be exercised by the mandatary State shall, if not previously agreed upon by the high contracting parties in each case, be explicitly defined by the executive council in a special act or charter.

The high contracting parties further agree to establish at the seat of the league a mandatary commission to receive and examine the annual reports of the mandatory powers, and to assist the league in insuring the observance of the terms of all mandates.

\section{Article 20}

The high contracting parties will endeavor to secure and maintain fair and humane conditions of labor for men, women, and children, both in their own countries and in all countries to which their commercial and industrial relations extended; and to that end agree to establish as part of the organization of the league a permanent bureau of labor.

\section{Article 21}

The high contracting parties agree that provision shall be made through the instrumentality of the league to secure and maintain freedom of transit and equitable treatment for the commerce of all council an annual report in reference to the territory committed to its charge.

The degree of authority, control, or administration to be exercised by the mandatary shall, if not previously agreed upon by the members of the league, be explicitly defined in each case by the council.

A permanent commission shall be constituted to receive and examine the annual reports of the mandataries and to advise the council on all matters relating to the observance of the mandates.

See Par. 6, Article 23. 
States members of the league, having in mind, among other things, special arrangements with regard to the necessities of the regions devastated during the war of 1914-1918.

See Article 20.

See Article 18.

\section{Article 23}

Subject to and in accordance with the provisions of international conventions existing or hereafter to be agreed upon, the members of the league:

(a) will endeavor to secure and maintain fair and humane conditions of labor for men, women, and children, both in their own countries and in all countries to which their commercial and industrial relations extend, and for that purpose will establish and maintain the necessary international organizations;

(b) undertake to secure just treatment of the native inhabitants of territories under their control;

(c) will intrust the league with the general supervision' over the execution of agreements with regard to the traffic in women and children and the traffic in opium and other dangerous drugs;

(d) will intrust the league with the general supervision of the trade in arms and ammunition with the countries in which the control of this traffic is necessary in the common interest;

(e) will make provision to secure and maintain freedom of 
See Article 21.

See Article 25.

Article 22

The high contracting parties agree to place under the control of the league all international bureaus already established by general treaties if the parties to such treaties consent. Furthermore, they agree that all such international bureaus to be constituted in future shall be placed under the control of the league. communication and of transit and equitable treatment for the commerce of all members of the league. In this connection the special necessities of the regions devastated during the war of 1914-1918 shall be borne in mind;

( $f$ ) will endeavor to take steps in matters of international concern for the prevention and control of disease.

\section{Article 24}

There shall be placed under the direction of the league all international bureaus already established by general treaties if the parties to such treaties consent. All such international bureaus and all commissions for the regulation of matters of international interest hereafter constituted shall be placed under the direction of the league.

In all matters of international interest which are regulated by general conventions but which are not placed under the control of international bureaus or commissions, the secretariat of the league shall, subject to the consent of the council and if desired by the parties, collect and distribute all relevant information and shall render any other assistance which may be necessary or desirable.

The council may include as part of the expenses of the secretariat the expenses of any bureau or commission which is placed under the direction of the league. 


\section{Article 23}

The high contracting parties agree that every treaty or international engagement entered into hereafter by any State member of the league shall be forthwith registered with the secretary general and as soon as possible published by him, and that no such treaty or international engagement shall be binding until so registered.

\section{Article 24}

It shall be the right of the body of delegates from time to time to advise the reconsideration by State members of the league of treaties which have become inapplicable and of international conditions of which the continuance may endanger the peace of the world.
See Article 18.

See Article 19.

\section{Article 25}

The members of the league agree to encourage and promote the establishment and coöperation of duly authorized voluntary national Red Cross organizations having as purposes improvement of health, the prevention of disease and the mitigation of suffering throughout the world.
ARTICLE 25

The high contracting parties severally agree that the present covenant is accepted as abrogating all obligations inter se which 


\section{APPENDIX}

are inconsistent with the terms thereof, and solemnly engage that they will not hereafter enter into any engagements inconsistent with the terms thereof. In case any of the powers signatories hereto or subsequently admitted to the league shall before becoming a party to this covenant have undertaken any obligations which are inconsistent with the terms of this covenant, it shall be the duty of such power to take immediate steps to procure its release from such obligations.

\section{Article 26}

Amendments to this covenant will take effect when ratified by the States whose representatives compose the executive council and by three-fourths of the States whose representatives compose the body of delegates.
See Article 20.

Article 26

Amendments to this covenant will take effect when ratified by the members of the league whose representatives compose the council and by a majority of the members of the league whose representatives compose the assembly.

No such amendment shall bind any member of the league which signifies its dissent therefrom, but in that case it shall cease to be a member of the league.

\section{Annex to the Covenant}

1. Original members of the league of nations.

Signatories of the treaty of peace: United States of America, Belgium, Bolivia, Brazil, British Empire, Canada, Australia, South Africa, New Zealand, India, China, Cuba, Czechoslovakia, 
Ecuador, France, Greece, Guatemala, Haiti, Hedjaz, Honduras, Italy, Japan, Liberia, Nicaragua, Panama, Peru, Poland, Portugal, Roumania, Serb-Croat-Slovene State, Siam, Uruguay.

States invited to accede to the covenant: Argentina, Chile, Colombia, Denmark, Netherlands, Norway, Paraguay, Persia, Salvador, Spain, Sweden, Switzerland, Venezuela.

2. First secretary general of the league of nations. The Honorable Sir James Eric Drummond, K.C.M.G., C.B. 


\section{APPENDIX No. IV}

Compiled by Dr. DenYs P. MYers of the World Peace Foundation; reprinted by permission.

\section{International Administrative Organizations}

1. Régime of free navigation on international rivers, 1815 .

2. International Sanitary Union, with permanent bureau, 1851. For additional protection against the spread of epidemics the following organizations have been established:

(a) International Sanitary Council of Tangier, Morocco, 1818.

(b) Superior Sanitary Council of Constantinople, 1894.

(c) Maritime and Quarantine Sanitary Council of Egypt, 1892.

(d) International Office of Public Hygiene, 1907.

3. Régime of free navigation on the Danube, 1856.

4. Universal Postal Union, with permanent bureau, 1863.

5. Improvement of the lot of sick and wounded in armies in the field (Red Cross Convention), 1864.

6. International Association for the Measurement of the Earth, with permanent bureau, 1864.

\%. Universal Telegraphic Union, with permanent bureau, 1865.

8. Latin Monetary Union, 1865.

9. Maintenance of Lighthouse at Cape Spartel, Morocco, 1865.

10. Scandinavian Monetary Union, 1875.

11. International Bureau of Weights and Measures, 1875.

12. International Conference against Phylloxera (plant lice), 1878.

13. Transportation of Merchandise by Railroads in Europe, with permanent bureau, 1878 .

14. Publication of Customs Tariffs, with permanent bureau, 1880 .

15. Protection of Industrial Property, with permanent bureau, 1880.

16. Protection of Literary and Artistic Property, with permanent bureau, 1880.

17. Protection of Submarine Cables, 1882.

18. Regulation of Fisheries Police in the North Sea, 1882.

19. Technical Unification of European Railroads, 1882.

20. International Conference for the Choice of a Prime Meridian, 1884.

21. Exchange of Reproductions of Works of Art, 1885. 
22. Exchange of Official Documents, Scientific and Literary Publications, with numerous bureaus of exchange, 1886.

23. Régime of the Suez Maritime Canal, 1888.

24. International Maritime Conferences, 1889.

25. Pan American Union, 1889.

26. Legal Protection of Workers, 1890.

27. Repression of the African Slave Trade, with permanent bureau, 1890.

28. Unification of Private International Law, 1893.

29. Gauging of Non-Seagoing Vessels, 1898.

30. Regulation of the Importation of Spirituous Liquors into Certain Regions of Africa, 1899.

31. Permanent Court of Arbitration, with permanent bureau, 1899.

32. Permanent International Council for the Exploration of the Sea, with permanent central bureau and international laboratory, 1899.

33. Conservation of Wild Animals in Africa, 1900.

34. Revision of the Nomenclature of Causes of Death, 1900. .

35. Protection of Insectivorous Birds Useful to Agriculture, 1902.

36. International Sugar Union, with permanent bureau, 1902.

37. Pan American Sanitary Convention, with permanent bureau, 1902.

38. Unification of the Formulas of Potent Drugs, 1902.

39. International Association of Seismology, with permanent bureau, 1903.

40. Repression of the Trade in White Women, 1904 .

41. Unification of Maritime Law, 1905.

42. International Institute of Agriculture, with permanent bureau, 1905.

43. Wireless Telegraphic Union, with permanent bureau, 1906.

44. Central American Court of Justice, International Bureau and Conferences, 1907.

45. International Committee for Making a Map of the World, 1909.

46. Regulation of the Arms Trade in Africa, 1909.

47. Repression of the Use of Opium, 1909.

48. Regulation of the Use of Saccharine, 1909.

49. Repression of the Circulation of Obscene Publications, 1910.

50. Unification of Commercial Statistics, 1910.

51. South American Postal Union, 1911.

52. Protection of Seals and Maritime Otters, 1911.

53. International Regulation of Standard Time, 1912. 


\title{
APPENDIX No. V
}

\section{TABLES SHOWING THE CASES DECIDED AND THE RATIFICATION OF CONVENTIONS}

\author{
Reprinted by courtesy of the World Peace Foundation
}




\section{APPENDIX}

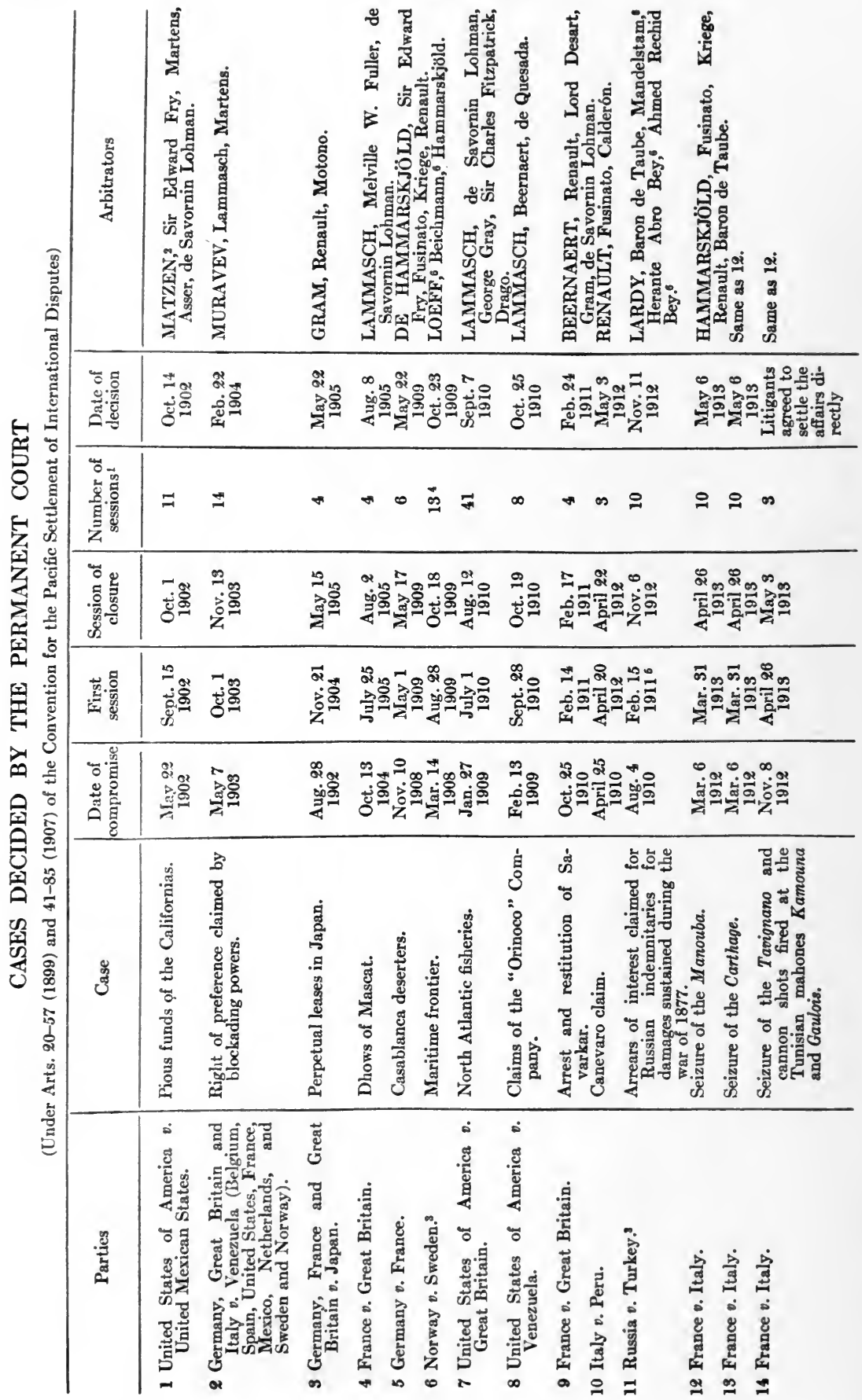




\section{APPENDIX}

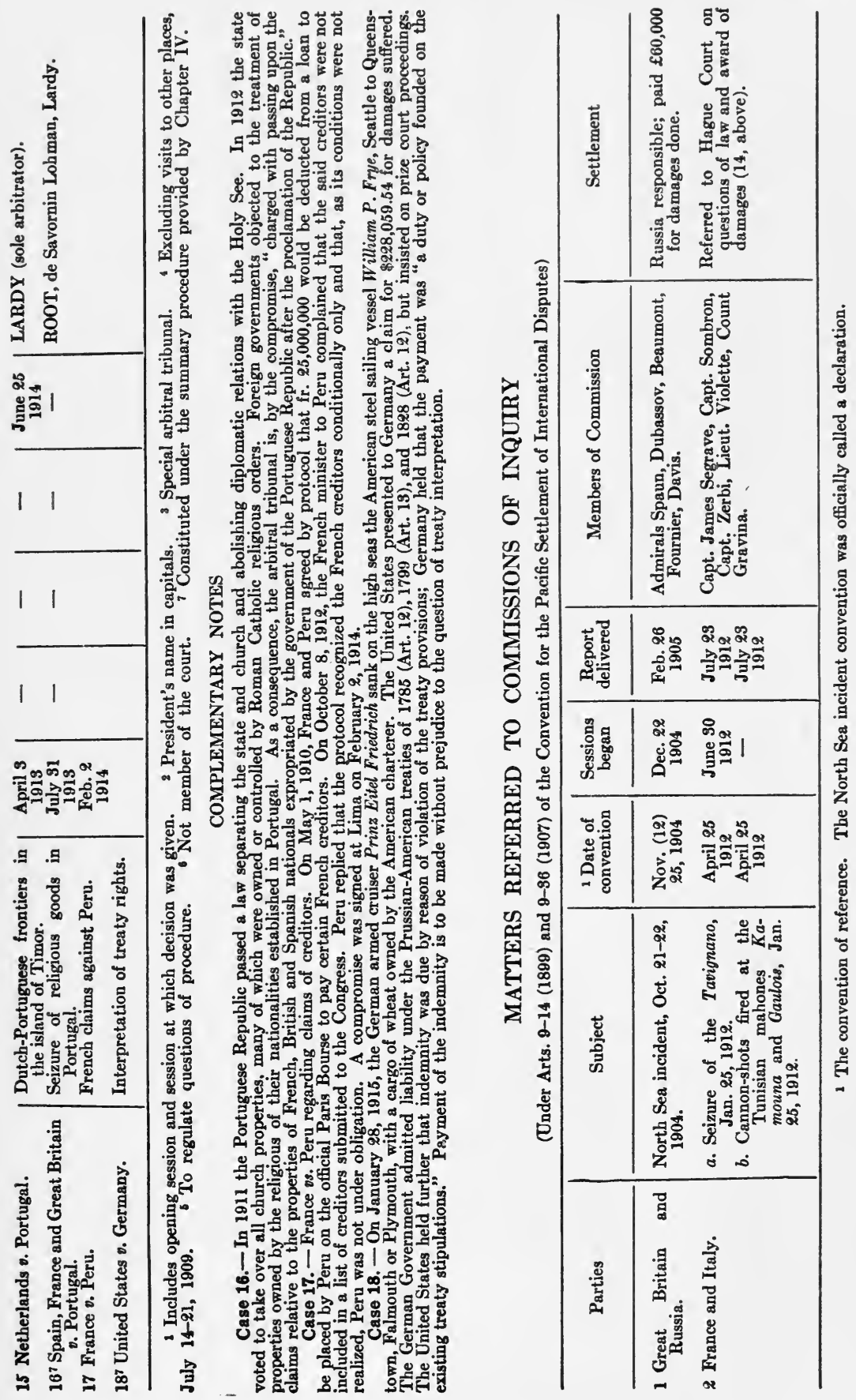




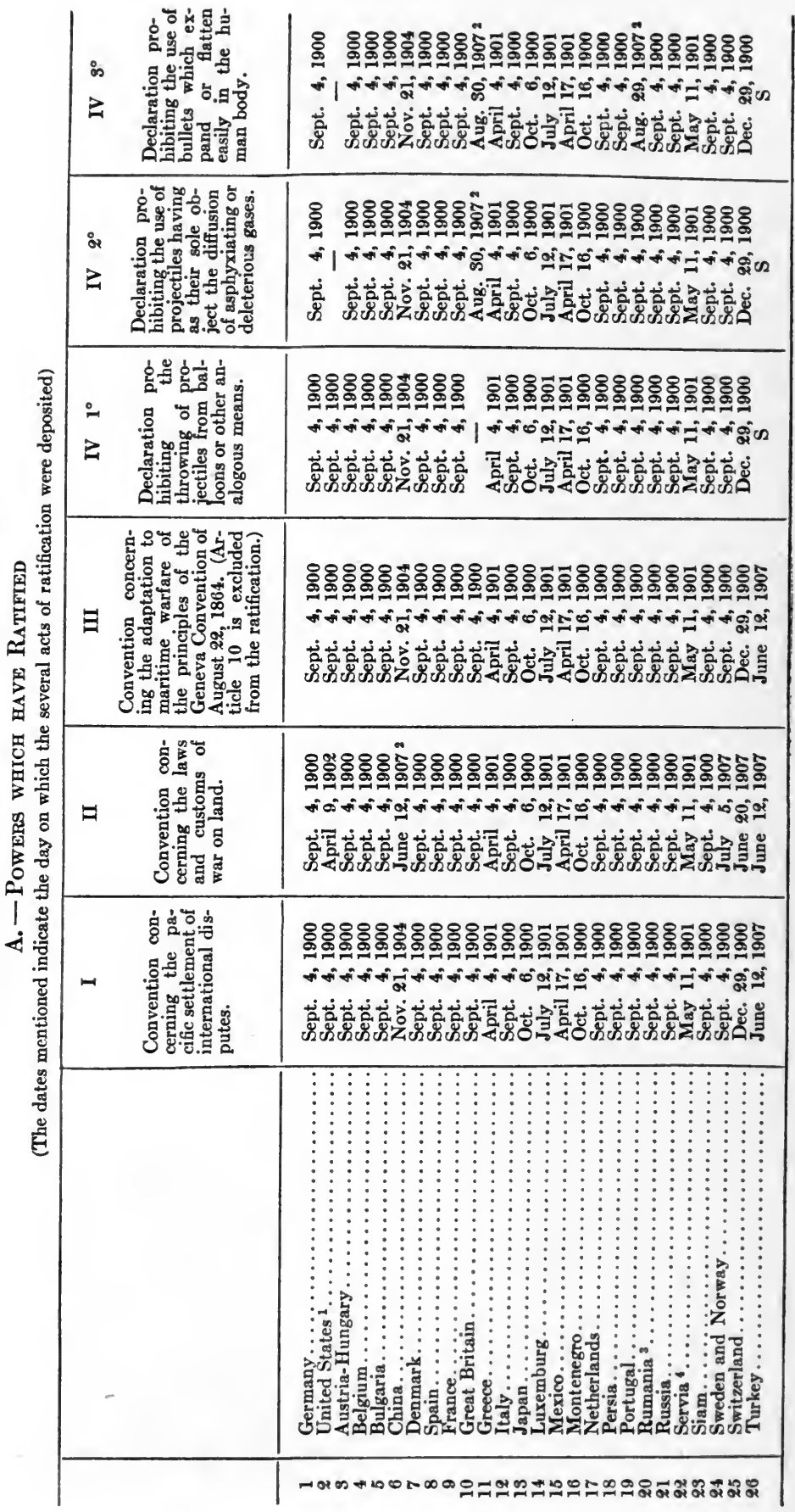




\section{APPENDIX}

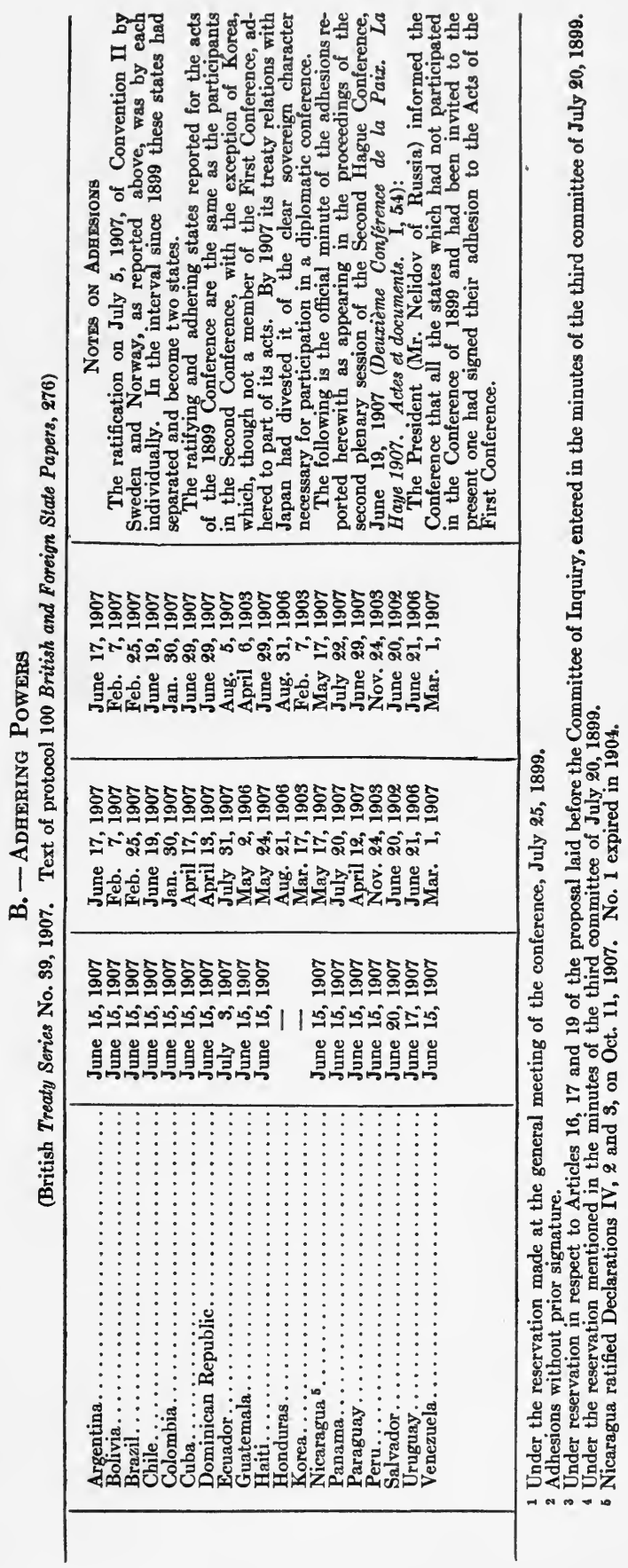




\begin{tabular}{|c|c|c|}
\hline$\vec{x}$ & 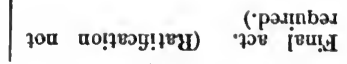 & $\operatorname{Cos} 02020202$ \\
\hline 蛋 & 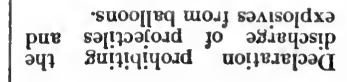 & 1 ฝึ่อ \\
\hline$\exists$ & 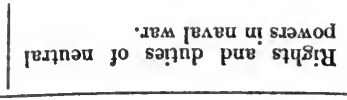 & बृత్ \\
\hline 可 & 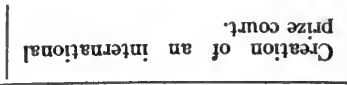 & थ 苞 \\
\hline $\bar{x}$ & 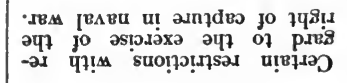 & 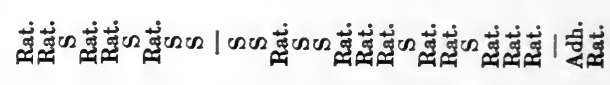 \\
\hline$x$ & 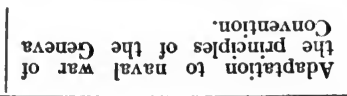 & 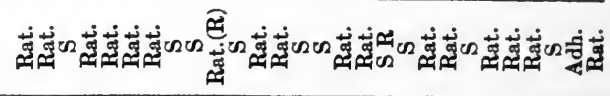 \\
\hline 层 & 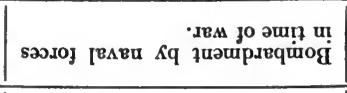 & 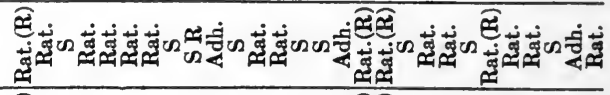 \\
\hline 寻 & 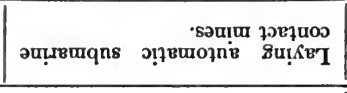 & 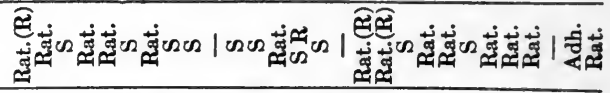 \\
\hline 5 & 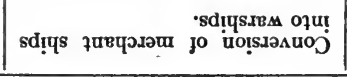 & 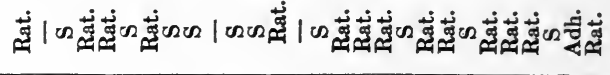 \\
\hline 5 & 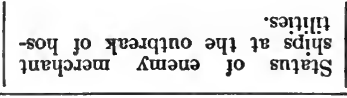 & 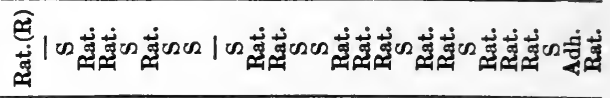 \\
\hline$>$ & 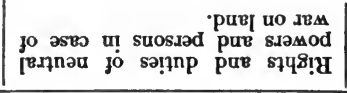 & 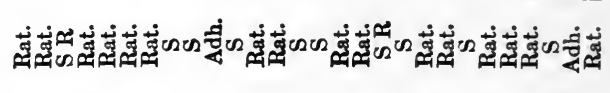 \\
\hline$Z$ & uo ses fo suropsno pur sMET & 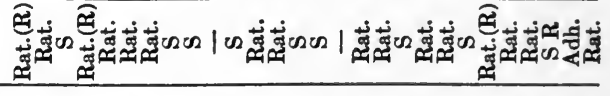 \\
\hline$\Xi$ & -soप jo suḷado of & 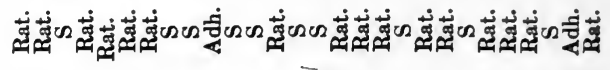 \\
\hline$\Xi$ & 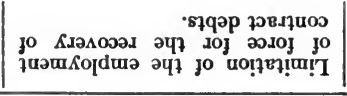 & 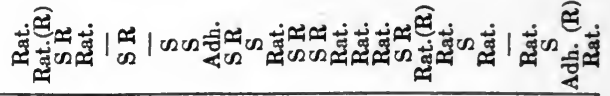 \\
\hline - & 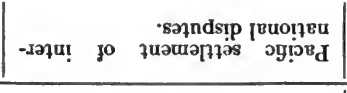 & થึં \\
\hline & 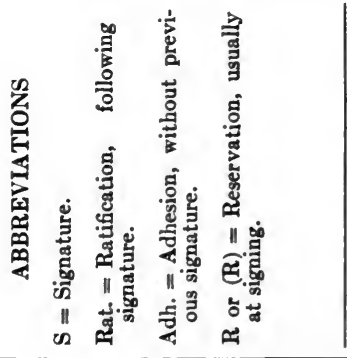 & 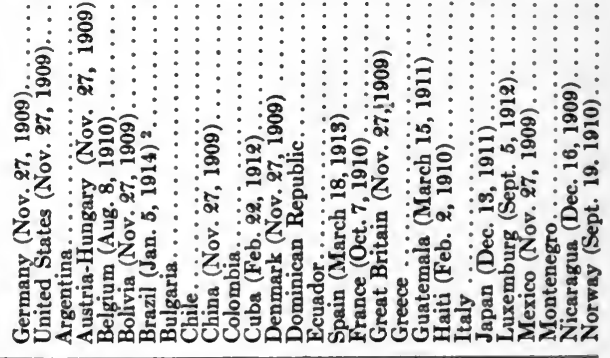 \\
\hline & & \\
\hline
\end{tabular}




\section{APPENDIX}

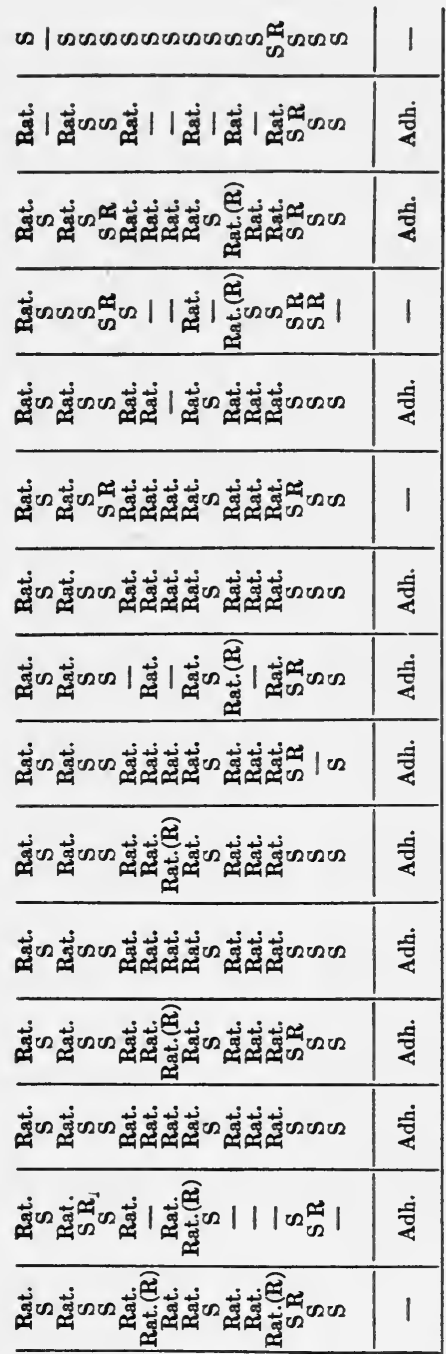

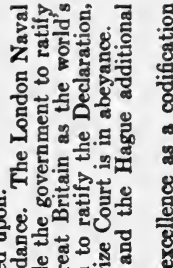

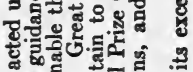

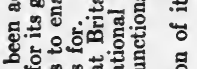

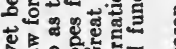

¿日.

을

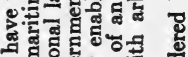

3.

di을

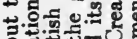

of

\% 8 .

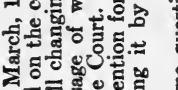

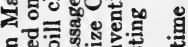

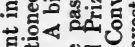

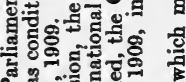

का

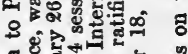

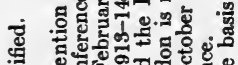

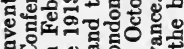

당

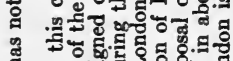

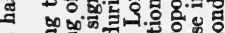

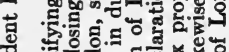

\%

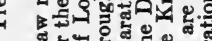

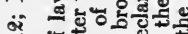

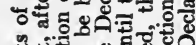

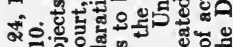

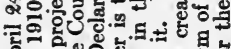
ऊंक. ษ \%ั.

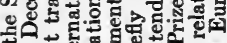

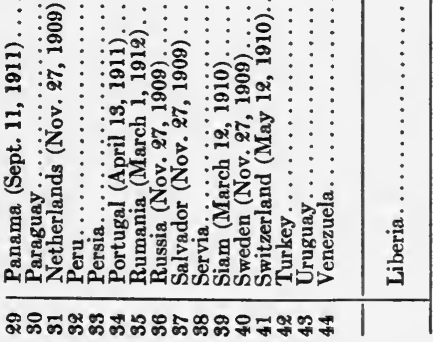
of

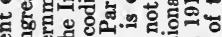


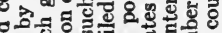

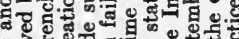
8 o 5 o

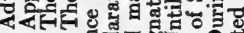
$\cdots \infty-5,50$.

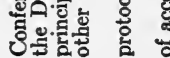




\section{ANALYSIS OF 1907 RATIFICATIONS}

\section{By Conventions}

I. - Pacific settlement
of international dis-
putes............
II. - Limitation of
the employment of
force for the re-
covery of contract
debts...........
III. - Relative to opening of hostilities..............

IV. - Laws and customs of war on land

V. - Rights and duties of neutral powers and persons in case of war on land............

VI. - Status of enemy merchant ships at the outbreak of hostilities.......

VII. - Conversion of merchant ships into warships..........

VIII. - Laying automatic submarine contact mines.....

IX. - Bombardment by naval forces in time of war.......

X. - Adaptation to naval war of the principles of the Geneva Convention

XI. - Certain restrictions with regard to the exercise of the right of capture in naval war......

XII. - Creation of an international prize court............

XIII. - Rights and duties of neutral powers in naval war $\begin{array}{cc}\text { Sig- } & \text { * Ratifi- } \\ \text { natures } & \text { cations }\end{array}$

$43 \quad(8 \mathrm{R}) \quad 27 \quad(1 \mathrm{adh}.) \dagger(5 \mathrm{R})$

$42 \quad$ (2R) $28 \quad$ (3 adh.)

$34(10 \mathrm{R}) \quad 21 \quad(4 \mathrm{adh}) \quad.(4 \mathrm{R})$

$42 \quad 28 \quad(3 \mathrm{adh}$.

$41 \quad(6 \mathrm{R}) \quad 27 \quad(2 \mathrm{adh}) \quad.(4 \mathrm{R})$

$41 \quad(2 R) \quad 26 \quad(2$ adh. $) \quad(2 R)$

$39 \quad$ (IR) $25 \quad(2 \mathrm{adh}$.

$\begin{array}{lllll}37 \quad(6 \mathrm{R}) & 22 & (2 \mathrm{adh} .) & (4 \mathrm{R})\end{array}$

$41 \quad(5 \mathrm{R}) \quad 29 \quad(4 \mathrm{adh}) \quad.(4 \mathrm{R})$

$49 \quad(4 \mathrm{R}) \quad 27 \quad(1 \mathrm{adh}$.$) \quad (1R)$

$40 \quad 25 \quad(2 \mathrm{adh}$.

32 (10R) 7

$39 \quad(7 R) \quad 25 \quad(4$ adh.) (6R)

XIV. - Declaration prohibiting the discharge of projectiles and explosives from balloons.....

XV. - Final act.... Totals..........

Deducting signatures

to Final Act.... 43 (1R)
$27 \quad 17$ ( 2 adh.)

49 (IR) Not required $584(62 R)$

\section{By States}

* Sig-

natures

Germany....... 14 (5R) 12

United States... 12 (1R) 12

Argentina..... 15 (RR) -

Austria-Hungary 15 (1R) 12

Belgium....... 14 14

Bolivia......... 15 (1R) 7

Brazil........ 19 (1R) 12

Bulgaria....... 15

Chile......... 14 (3R) -

China........ 4 (1R) 8

Colombia..... 15 (1R) -

Cuba......... 14 (IR)

Denmark....... $14 \quad 12$

Dominican Republic....... 13 (3R) -

Ecuador....... 15 (2R) -

Spain......... 10.

France........ 14 (2R) 12

Great Britain... $15 \quad(5 R) \quad 9$

Greece........ 14 (2R) -

Guatemala..... 14 (2R) 19

Haiti......... 15 (1R) 14

Italy........ 14 14

Japan......... 13 (4R) 12

Liberia........ -

Luxemburg..... 19

Mexico........ 14

Montenegro.... 11

Nicaragua..... 1

Norway....... 15

Panama...... 15

Paraguay....... 13

Netherlands.... 15

Peru......... 15

Persia........ 15

Portugal...... 14

Rumania....... 12

Russia......... 11

Salvador....... 15

Servia........ 13

Siam......... 14

Sweden....... 12

Switzerland..... $14 \quad$ (2R) 12

Turkey....... $15 \quad(7 \mathrm{R})$ -

Uruguay...... 14 (2R) -

Venezuela..... 12 -

Totals.... $\overline{584(62 R)}$

Deducting signatures to Final Act (ratification not required)..... $43 \quad$ (1R)
- Ratifi-

$(5 R$

(1 adh.)† (SR)

(1R)

(5 adh.) (2R)

(1 adh.)

(11 adh.) 12

13

13 (13 adh.) (1R) 13

14

13

(1R) -

(3R) -

(1R) 12 (1 adh.) (1R)

(2R) $10 \quad$ (2R)

(QR)

(3R)

(1R)

- Parenthesized details indicate reservations.

† Adhesions are separately noted, though included in the total. 


\section{APPENDIX No. VI}

\section{DECLARATION OF THE RIGHTS AND DUTIES OF NATIONS ${ }^{1}$}

"I. Every nation has the right to exist and to protect and conserve its existence, but this right neither implies the right nor justifies the act of the State to protect itself or to conserve its existence by the commission of unlawful acts against innocent and unoffending States.

"II. Every nation has the right to independence in the sense that it has a right to the pursuit of happiness and is free to develop itself without interference or control from other States, provided that in so doing it does not interfere or violate the rights of other States.

"III. Every nation is in law and before law the equal of every other nation belonging to the society of nations, and all nations have the right to claim and, according to the Declaration of Independence of the United States, 'to assume among the powers of the earth, the separate and equal station to which the laws of nature and of nature's God entitle them.'

"IV. Every nation has the right to territory within defined boundaries and to exercise exclusive jurisdiction over its territory and all persons, whether native or foreign, found therein.

"V. Every nation entitled to a right by the law of nations is entitled to have that right respected and protected by all other nations, for right and duty are correlative, and the right of one is the duty of all to observe.

"VI. International law is at one and the same time both national and international; national in the sense that it is the law of the land ${ }^{2}$ and is applicable as uch to the decision of all questions involving its principles; international in the sense that it is the law of the society of nations and applicable as such to all questions between and among the members of the society of nations involving its principles."

1 Adopted by the American Institute of International Law, Washington, January 6. 1916.

2 Article 4 of the Constitution of the German Commonwealth, adopted August 11, 1919, provides:

"The generally recognized principles of the law of nations are accepted as an integral part of the law of the German Commonwealth." (Trans. by W. B. Munro and A. N. Holcombe, World Peace Foundation, Vol. II, No. 6, Dec., 1919.) 


\section{APPENDIX No. VII ${ }^{1}$}

\section{DRAFT SCHEME FOR THE INSTITUTION OF THE PER- MANENT COURT OF INTERNATIONAL JUSTICE}

Mentioned in Article 14 of the Covenant of the League of Nations.

Presented to the Council of the League by the

Advisory Committee of Jurists

\section{Article 1}

A Permanent Court of International Justice, to which Parties shall have direct access, is hereby established, in accordance with Article 14 of the Covenant of the League of Nations. This Court shall be in addition to the Court of Arbitration organized by the Hague Convention of 1899 and 1907, and to the special Tribunals of Arbitration to which States are always at liberty to submit their disputes for settlement.

\section{CHAPTER I \\ Organization of the Court}

Article 2

The Permanent Court of International Justice shall be composed of a body of independent judges, elected regardless of their nationality, from among persons of high moral character, who possess the qualifications required, in their respective countries, for appointment to the highest judicial offices, or are jurisconsults of recognized competence in international law.

\section{Article 3}

The Court shall consist of 15 members: 11 judges and 4 deputyjudges. The number of judges and deputy-judges may be hereafter increased by the Assembly, upon the proposal of the Council of the League of Nations, to a total of 15 judges and 6 deputy-judges.

1 See note accompanying Appendix VIII. 


\section{Article 4}

The members of the Court shall be elected by the Assembly and the Council from a list of persons nominated by the national groups in the Court of Arbitration, in accordance with the following provisions.

\section{Article 5}

At least three months before the date of the election, the SecretaryGeneral of the League of Nations shall address a written request to the members of the Court of Arbitration, belonging to the States mentioned in the Annex to the Covenant or to the States which shall have joined the League subsequently, inviting them to undertake, by national groups, the nomination of persons in a position to accept the duties of 'a member of the Court.

No group may nominate more than two persons; the nominees may be of any nationality.

\section{Article 6}

Before making these nominations, each national group is hereby recommended to consult its Highest Court of Justice, its Legal Faculties and Schools of Law, and its National Academies and national sections of International Academies devoted to the study of Law.

\section{Article 7}

The Secretary-General of the League of Nations shall prepare a list, in alphabetical order, of all the persons thus nominated. These persons only shall be eligible for appointment, except as provided in Article 12, paragraph 2.

The Secretary-General shall submit this list to the Assembly and to the Council.

\section{Article 8}

The Assembly and the Council shall proceed to elect by independent voting first the judges and then the deputy-judges.

\section{Article 9}

At every election, the electors shall bear in mind that not only should all the persons appointed as members of the Court possess the qualifications required, but the whole body also should represent the main forms of civilization and the principal legal systems of the world. 


\section{Article 10}

Those candidates who obtain an absolute majority of votes in the Assembly and the Council shall be considered as elected.

In the event of more than one candidate of the same nationality being elected by the votes of both the Assembly and the Council, the eldest of these only shall be considered as elected.

\section{Article 11}

If, after the first sitting held for the purpose of the election, one or more seats remain to be filled, a second, and if necessary, a third sitting shall take place.

\section{Article 12}

If after the third sitting one or more seats still remain unfilled, a joint Conference consisting of six members, three appointed by the Assembly and three by the Council, may be formed, at any time, at the request of either the Assembly or the Council, for the purpose of choosing one name for each seat still vacant, to submit to the Assembly and the Council for their respective acceptance.

If the Committee is unanimously agreed upon any person who fulfills the required conditions, he may be included in its list, even though he was not included in the list of nominations made by the Court of Arbitration.

If the Joint Conference is not successful in procuring an election, those members of the Court who have already been appointed shall, within a time limit to be arranged by the Council, proceed to fill the vacant seats by selection from among those candidates who have obtained votes either in the Assembly or in the Council.

In the event of an equality of votes among the judges, the eldest judge shall have a casting vote.

\section{Article 13}

The members of the Court shall be elected for nine years.

They may be re-elected.

They shall continue to discharge their duties until their places have been filled.

Though replaced, they shall complete any cases which they may have begun. 


\section{APPENDIX}

\section{Article 14}

Vacancies which may occur shall be filled by the same method as that laid down for the first election.

A member of the Court elected to replace a member the period of whose appointment has not expired will hold the appointment for the remainder of his predecessor's term.

\section{Article 15}

Deputy-judges shall be called upon to sit in the order laid down in a list.

This list shall be prepared by the Court, having regard first to the order in time of each election and secondly to age.

\section{Article 16}

The exercise of any function which belongs to the political direction, national or international, of States, by the Members of the Court, during their terms of office is declared incompatible with their judicial duties.

Any doubt upon this point is settled by the decision of the Court.

\section{Article 17}

No member of the Court can act as agent, counsel or advocate in any case of an international nature.

No member may participate in the decision of any case in which he has previously taken an active part, as agent, counsel or advocate for one of the contesting parties, or as a member of a national or international Court, or of a Commission of Inquiry, or in any other capacity.

Any doubt upon this point is settled by the decision of the Court.

\section{Article 18}

A member of the Court can not be dismissed unless, in the unanimous opinion of the other Members, he has ceased to fulfill the required conditions.

When this happens a formal notification shall be given to the Secretary-General.

This notification makes the place vacant.

\section{Article 19}

The members of the Court, when outside their own country, shall enjoy the privileges and immunities of diplomatic representatives. 


\section{Article 20}

Every member of the Court shall, before taking up his duties, make a solemn declaration in open Court that he will exercise his powers impartially and conscientiously.

\section{Article 21}

The Court shall elect its President and Vice-President for three years; they may be re-elected.

It shall appoint its Registrar.

The duties of Registrar of the Court shall not be considered incompatible with those of Secretary-General of the Permanent Court of Arbitration.

\section{Article 22}

The seat of the Court shall be established at The Hague.

The President and Registrar shall reside at the seat of the Court.

\section{ARticle 23}

A session shall be held every year.

Unless otherwise provided by rules of Court this session shall begin on the 15th June, and shall continue for so long as may be necessary to complete the cases on the list.

The President may summon an extraordinary meeting of the Court whenever necessary.

\section{Article 24}

If, for some special reason, a member of the Court considers that he can not take part in the decision of a particular case, he shall so inform the President.

If, for some special reason, the President considers that one of the members of the Court should not sit on a particular case, he shall give notice to the member concerned.

In the event of the President and the member not agreeing as to the course to be adopted in any such case, the matter shall be settled by the decision of the Court.

\section{Article 25}

The full Court shall sit except when it is expressly provided otherwise.

If 11 judges can not be present, deputy-judges shall be called upon to sit, in order to make up this number.

If, however, 11 judges are not available, a quorum of 9 judges shall suffice to constitute the Court. 


\section{Article 26}

With a view to the speedy dispatch of business the Court shall form, annually, a chamber composed of three judges who, at the request of the contesting parties, may hear and determine cases by summary procedure.

\section{Article 27}

The Court shall frame rules for regulating its procedure. In particular, it shall lay down rules for summary procedure.

\section{Article 28}

Judges of the nationality of each contesting party shall retain their right to sit in the case before the Court.

If the Court includes upon the Bench a judge of the nationality of one of the parties only, the other party may select from among the deputy-judges, a judge of its nationality, if there be one. If there should not be one, the party may choose a judge, preferably from among those persons who have been nominated as candidates by some national group in the Court of Arbitration.

If the Court includes upon the Bench no judge of the nationality of the contesting parties, each of these may proceed to select or choose a judge as provided in the preceding paragraph.

Should there be several parties in the same interest, they shall, for the purpose of the preceding provisions, be reckoned as one party only.

Judges selected or chosen as laid down in paragraphs 2 and 3 of this Article shall fulfill the conditions required by Articles 2, 16, 17, 20, 24 of this Statute. They shall take part in the decision on an equal footing with their colleagues.

\section{Article 29}

The judges shall receive an annual salary to be determined by the Assembly of the League of Nations upon the proposal of the Council. This salary must not be decreased during the period of a judge's appointment.

The President shall receive a special grant for his period of office, to be fixed in the same way.

Deputy-judges shall receive a grant, for the actual performance of their duties, to be fixed in the same way.

Traveling expenses incurred in the performance of their duties shall be refunded to judges and deputy-judges who do not reside at the seat of the Court. 
Grants due to judges selected or chosen as provided in Article 28 shall be determined in the same way.

The salary of the Registrar shall be decided by the Council upon the proposal of the Court.

A special regulation shall provide for the pensions to which the judges and registrar shall be entitled.

\section{Article 30}

The expenses of the Court shall be borne by the League of Nations, in such a manner as shall be decided by the Assembly upon the proposal of the Council.

\section{CHAPTER II \\ Competence of the Court}

Article 31

The Court shall have jurisdiction to hear and determine suits between States.

\section{Article 32}

The Court shall be open of right to the States mentioned in the Annex to the Covenant, and to such others as shall subsequently enter the League of Nations.

Other States may have access to it.

The conditions under which the Court shall be open of right or accessible to States which are not Members of the League of Nations shall be determined by the Council, in accordance with Article 17 of the Covenant.

\section{Article 33}

When a dispute has arisen between States, and it has been found impossible to settle it by diplomatic means, and no agreement bas been made to choose another jurisdiction, the party complaining may bring the case before the Court. The Court shall, first of all, decide whether the preceding conditions have been complied with; if so, it shall hear and determine the dispute according to the terms and within the limits of the next Article.

\section{Article 34}

Between States which are Members of the League of Nations, the Court shall have jurisdiction (and this without any special convention 
giving it jurisdiction) to hear and determine cases of a legal nature concerning:

(a) the interpretation of a treaty;

(b) any question of international law;

(c) the existence of any fact which, if established, would constitute a breach of an international obligation;

(d) the nature or extent of reparation to be made for the breach of an international obligation;

(e) the interpretation of a sentence passed by the Court.

The Court shall also take cognizance of all disputes of any kind which may be submitted to it by a general or particular convention between the parties.

In the event of a dispute as to whether a certain case comes within any of the categories above mentioned, the matter shall be settled by the decision of the Court.

\section{Article 35}

The Court shall, within the limits of its jurisdiction as defined in Article 34, apply in the order following:

1. international conventions, whether general or particular, establishing rules expressly recognized by the contesting States;

2. international custom, as evidence of a general practice, which is accepted as law;

3. the general principles of law recognized by civilized nations;

4. judicial decisions and the teachings of the most highly qualified publicists of the various nations, as subsidiary means for the determination of rules of law.

\section{Article 36}

The Court shall give an advisory opinion upon any question or dispute of an international nature referred to it by the Council or Assembly.

When the Court shall give an opinion on a question of an international nature which does not refer to any dispute that may have arisen, it shall appoint a special Commission . of from three to five members.

When it shall give an opinion upon a question which forms the subject of an existing dispute, it shall do so under the same conditions as if the case had been actually submitted to it for decision. 


\section{CHAPTER III}

\section{Procedure}

\section{Article 37}

The official language of the Court shall be French.

The Court may, at the request of the contesting parties, authorize another language to be used before it.

\section{Article 38}

A State desiring to have recourse to the Court shall lodge a written application addressed to the Registrar.

The application shall indicate the subject of the dispute, and name the contesting parties.

The Registrar shall forthwith communicate the application to all concerned.

He shall also notify the Members of the League of Nations through the Secretary-General.

\section{Article 39}

If the dispute arises out of an act which has 'already taken place or which is imminent, the Court shall have the power to suggest, if it considers that circumstances so require, the provisional measures that should be taken to preserve the respective rights of either party.

Pending the final decision, notice of the measures suggested shall forthwith be given to the parties and the Council.

\section{Article 40}

The parties shall be represented by agents.

They may have Counsel or Advocates to plead before the Court.

\section{Article 41}

The procedure shall consist of two parts: written and oral.

Article 42

The written proceedings shall consist of the communication to the judges and to the parties of statements of cases, counter-cases and, if necessary, replies; also all papers and documents in support. 
These communications shall be made through the Registrar in the order and within the time fixed by the Court.

A certified copy of every document produced by one party shall be communicated to the other party.

\section{Article 43}

The oral proceedings shall consist of the hearing by the Court of witnesses, experts, agents, counsel and advocates.

For the service of all notices upon persons other than the agents, counsel and advocates, the Court shall apply direct to the Government of the State upon whose territory the notice has to be served.

The same provision shall apply whenever steps are to be taken to procure evidence on the spot.

\section{Article 44}

The proceedings shall be under the direction of the President, or in his absence, of the Vice-President; if both are absent, the senior judge shall preside.

\section{Article 45}

The hearing in Court shall be public, unless the Court, at the written request of one of the parties, accompanied by a statement of his reasons, shall otherwise decide.

\section{Article 46}

Minutes shall be made at each hearing, and signed by the Registrar and the President.

These minutes shall be the only authentic record.

\section{Article 47}

The Court shall make orders for the conduct of the case, shall decide the form and time in which each party must conclude its arguments, and make all arrangements connected with the taking of evidence.

\section{Article 48}

The Court may, even before the hearing begins, call upon the agents to produce any document, or to supply to the Court any explanations. Any refusal shall be recorded.

\section{Artiche 49}

The Court may, at any time, intrust any individual, bureau, commission or other body that it may select, with the task of carrying out an inquiry or giving an expert opinion. 


\section{Article 50}

During the hearing in Court, the judges may put any questions considered by them to be necessary, to the witnesses, agents, experts, advocates or counsel. The agents, advocates and counsel shall have the right to ask, through the President, any questions that the Court considers useful.

\section{Article 51}

After the Court has received the proofs and evidence within the time specified for the purpose, it may refuse to accept any further oral or written evidence that one party may desire to present unless the other side consents.

\section{Article 52}

Whenever one of the parties shall not appear before the Court, or shall fail to defend his case, the other party may call upon the Court to decide in favor of his claim.

The court must, before doing so, satisfy itself, not only that it has jurisdiction in accordance with Articles 33 and 34, but also that the claim is supported by substantial evidence and well founded in fact and law.

\section{Article 53}

When the agents, advocates and counsel, subject to the control of the Court, have presented all the evidence, and taken all other steps that they consider advisable, the President shall declare the case closed.

The Court shall withdraw to consider the judgment.

The deliberations of the Court shall take place in private and remain secret.

\section{Article 54}

All questions shall be decided by a majority of the judges present at the hearing.

In the event of an equality of votes, the President or his deputy shall have a casting vote.

\section{Article 55}

The judgment shall state the reasons on which it is based.

It shall contain the names of the judges who have taken part in the decision.

\section{Article 56}

If the judgment given does not represent, wholly or in part, the unanimous opinion of the judges, the dissenting judges shall be entitled 
to have the fact of their dissent or reservations mentioned in it. But the reasons for their dissent or reservations shall not be expressed in the judgment.

\section{ARticle 57}

The judgment shall be signed by the President and by the Registrar. It shall be read in open Court, due notice having been given to the agent.

\section{Article 58}

The judgment is final and without appeal. In the event of uncertainty as to the meaning or scope of the judgment, the Court shall construe it upon the request of any party.

\section{ARTicle 59}

An application for revision of a judgment can be made only when it is based upon the discovery of some new fact, of such a nature as to be a decisive factor, which fact was, when the judgment was given, unknown to the Court and also to the party claiming revision, always provided that such ignorance was not due to negligence.

The proceedings for revision will be opened by a judgment of the Court expressly recording the existence of the new fact, recognizing that it has such a character as to lay the case open to revision, and declaring the application admissible on this ground.

The Court may require previous compliance with the terms of the judgment before it admits proceedings in revision.

No application for revision may be made after the lapse of five years from the date of the sentence.

\section{Article 60}

Should a State consider that it has an interest of a legal nature which may be affected by the decision in the case, it may submit a request to the Court to be permitted to intervene as a third party.

It will be for the Court to decide upon this request.

\section{Article 61}

Whenever the construction of a convention in which States, other than those concerned in the case, are parties, is in question, the Registrar shall notify all such States forthwith.

Every State so notified has the right to intervene in the proceedings; 


\section{APPENDIX}

but if it uses this right, the construction given by the judgment will be as binding upon it as upon the original parties to the dispute.

Article 62

Unless otherwise decided by the Court, each party shall bear its own costs. 


\title{
APPENDIX No. VIII ${ }^{1}$
}

\author{
Sunderland House, Curzon Street, \\ LoNDon, W. I. \\ 27th August, 1920.
}

The Council of the League of Nations has the honor to communicate to the

Government the scheme presented by the International Committee of eminent jurists who were invited to submit plans for the establishment of a Permanent Court of International Justice, and who have recently concluded their deliberations at The Hague.

The Council do not propose to express any opinion on the merits of the scheme until they have had a full opportunity of considering it but they permit themselves to accompany the documents with the following observations.

The scheme has been arrived at after prolonged discussion by a most competent tribunal. Its members represented widely different national points of view; they all signed the Report. Its fate has therefore been very different from that of the plans for a Court of Arbitral Justice, which were discussed without result in 1907. Doubtless the agreement was not arrived at without difficulty. Variety of opinions, even among the most competent experts, is inevitable on a subject so perplexing and complicated. Some mutual concessions are therefore necessary if the failure of thirteen years ago is not to be repeated. The Council would regard an irreconcilable difference of opinion on the merits of the scheme as an international misfortune of the gravest kind. It would mean that the League was publicly compelled to admit its incapacity to carry out one of the most important of the tasks which it was invited to perform. The failure would be great and probably irreparable; for, if agreement proves impossible under circumstances apparently so favorable, it is hard to spee how and when the task of securing it will be successfully resumed.

It is in the spirit indicated by these observations that the Council on their part propose to examine the project submitted to them by the Committee of Jurists; and they trust that in the same spirit the Members of the League will deal with this all-important subject when the Council brings the recommendations before the Assembly.

1 Reprinted by courtesy of World Peace Foundation, Special Number, Sept., 1920. The letter of explanation accompanied the draft project which was sent to the Governments of all members of the League. 



\section{INDEX}

Alliance, definition of, and relation of League of Nations to, 52

American Institute of International Law, recommendations of Havana, 16

Angary, law of, 8

Assembly, composition, 75 (Art. 3); jurisdiction, 75 (Art. 3); and international law, 17-18; reconsideration of treaties by, 27; admission of new members, 74 (Art. 1); relation to amendments, 97 (Art. 26); reports by, 86 (Art. 15); relation to choice of judges for the Permanent Court of International Justice, 111-112 (Arts. 4, 8, 10-12); power in fixing the salaries of judges in the Permanent Court of International Justice, 115 (Art. 29); in determination of apportionment of expenses of the Permanent Court of International Justice, 116 (Art. 30)

Austin, John, views on international law, 5

Baldwin, Mr. Justice, opinion in Rhode Island v. Massachusetts 35-36.

British League of Free Nations Association, recommends codification of international law by League Council, 17

Bluntschli, J. K., letter to Francis Lieber on codification of international law, 15

Bourgeois, Léon, views on sanctions, 48

Bryan, W. J., conciliation treaties negotiated by, 10-11

Bryce, Lord James, letter to Theodore Marburg on justiciable questions, 37; views on sovereignty, 50

Butler, N. M., on the Hague Peace Conferences, 13

Carnegie, Andrew, views on sanctions, 46

Cecil, Lord Robert, views on sanctions, 46

Cherokee Nation v. Georgia, case of, 35
China, collective intervention in, 39

Conclusions, 58-59

Confederations, definition of, and relation to the League of Nations, 51-52

Congresses, Paris, 1856, 12; Geneva, 1864, 12; at The Hague, 12-13

Constitution of the United States, judicial expansion of, 11

Council, composition, 75-76 (Art. 4); disarmament duties, 79-81; jurisdiction, 76 (Art. 4); reports and inquiry by, 29, 81, 84-86 (Arts. 11, 12, 15, 16, 17); relation to amendments, 97 (Art. 26); relation to choice of judges for the Permanent Court of International Justice, 111-112 (Arts. 4, 8, 10-12); power in fixing salaries of judges for the Permanent Court of International Justice and in apportionment of the expense of the court, 115 (Art. 29), 116 (Art. 30).

Court, Permanent Court of International Justice (Art. 14); Draft Scheme for, Appendix No. VII; should give continuity to international law, 12

Custom, development of international law by, 9-10

Deserters at Casablanca, case of, $\mathbf{3 4}$

Doe $\boldsymbol{v}$. Braden, case of, 35

Duguit, L., views on sovereignty, 49

Equality, principle of equality in the League of Nations, 52-55; equality in the apportionment of expense, 54 ; in representation and voting power, 54-55

Fenwick, C. G., on the Hague Conventions and the codification of international law, 12-13

Field, David Dudley, Draft Outlines of an International Code, 14 
George, David Lloyd, on abolishment of war, 28; on League as a substitute of reason and justice for force and intrigue in international relations, 32

German Constitution, recognition of validity of international law, footnote 2, 6 and Appendix No. VI

Grotius, Hugo, conception of international law held by, 1

Hague Conventions, applicability during war, 22-27

Hall, W. E., on intervention, 39

Haskins, Charles H., on Commissions in the Versailles negotiations, 9

Hobbes, Thomas, conception of international law held by, 3

International Congresses, development of international law by, 12-13

Japanese House Tax, case of, 34

Judicial Decisions, development of international law by, 11-12

Justiciable Questions, discussion of, 34-38

Knox, P. C., on an international league making war an international crime, 28

Krehbiel, Edward, on international congresses as a method of developing international law, 12

Labor, International Labor Organization, 19-21; nine fundamental principles of, 20 ; relation of the fundamental principles to international law, 20-21

La Fontaine, Henri, on making war an illegal institution, 28

Lansing, Robert, views on an international code and its relation to the Permanent Court of International Justice, 17; on penalties for a breach of international law, 25

Lawrence, T. J., criticism of Austin's theory of international law, 6

League of Nations, conception of international law under, 6-7; juridical status of, 49-57; original and revised drafts of the Covenant arranged in parallel columns, Appendix No. III, 73-98
League to Enforce Peace, on a congress to codify rules of international law, 16; on settlement of justiciable questions, 36

Lieber, Francis, on right to make war, 41

Mandatary, definition of, 90-92, mandatary commission, 93 (Art. 22)

Marburg, Theodore, Introduction by, $\mathrm{v}$-vii; on right to make war at will, 28; Lord Bryce's letter to, footnote, 37

Martin $v$. Mott, case of, 35

Monroe Doctrine, 90 (Art. 21)

Montesquieu, C. L., on individual and united action, 31

Moore, J. B., on unrestricted right to make war, 31 ; on lack of a sanction in the international system, 48

Morgenthau, Henry, on intervention, 39

Neutrality, President Wilson on, 41; effect of League on, 41-44; Dr. Quincy Wright on, 42-43; Switzerland and, 43-44

Oppenheim, L., on the Hague Peace Conferences, 13; on complex questions, 37-38

Phillimore, Sir Robert, views on natural and positive law, 4-5

Pious Fund, case of, 34

Political Questions, 34-38

Pufendorf, S., conception of international law held by, 3-4

Rhode Island $v$. Massachusetts, case of, 35 Roosevelt, Theodore, view on a sanction for international court decisions, 45

Root, Elihu, letter of March 29, 1919, to Mr. Hays, 13; on change in theory of international law, 40; on the Hague Peace Conferences, 13; on justiciable questions, 37

Sanctions, 45-48; Mr. Roosevelt on, 45; Mr. Taft on, 46; Mr. Scott on, 46; Lord Robert Cecil on, 46; Mr. Carnegie on, 46; Mr. Lowell on, 47; juridical sanction proposed, 47; J. B. Moore on weakness of the international system, 
48; M. Bourgeois on sanctions of Versailles Covenant, 48

Scott, James Brown, on Judicial Arbitration Court and judicial decisions, 11-12; on sanctions, 46

Smith, Munroe, on accountability of a nation for a 'crime against civilization,' 40

Smuts, J. C., Proposals for a League of Nations, Appendix No. I, 61-65; definition of justiciable questions, footnote, 37

Sovereignty, 49-51; definition of, 49;

L. Duguit on, 49; Wheaton on, 49-50

State, definition of, 51; relation to League of Nations, 51

Stowell, Lord, prize decisions by, 11

Switzerland, neutrality of, 43-44

Taft, W. H., views on sanctions, 46

Treaties, development of international law by, 10-11; reconsideration of by Assembly, 27; registration of, 27 (Art. 18); abrogation of, 27 (Art. 20)
Triepel, H., criticism of the development of international law by one writer copying from another, 8

War, made illegal by covenant in certain instances, 30

Wheaton, Henry, views on sovereignty, 49-50

William II, and sanctity of treaties, 25

Wilson, George Grafton, The Hague Arbitration Cases, 34; Wilson and Tucker, International Law, 39

Wilson, Woodrow, on international law, 1; on neutrality, 41; on Belgium's restoration and validity of international law, 26

World Court League, recommendation for an international congress to codify international law, 16

Wright, Quincy, on effects of Covenant on theory of international law, 42-43

Writers, development of international law by, 8 





v

\section{University of Toronto Library}

DO NOT REMOVE

THE

CARD

FROM

THIS

POCKET

Acme Library Card Pocket

LOWE-MARTIN CO. LIMITED 
